\title{
Antioxidant and antidiabetic properties of isolated fractions from methanolic extract derived from the whole plant of Cleome viscosa $\mathrm{L}$.
}

\author{
Yarrappagaari Suresh', Gutha Rajasekar ${ }^{1}$, Thopireddy Lavanya², Benne Lakshminarsimhulu', \\ Kesireddy Sathyavelu Reddy ${ }^{2}$ and Saddala Rajeswara Reddy ${ }^{1 *}$ (D)
}

\begin{abstract}
Background: Cleome viscosa is considered as an important medicinal plant extensively used in India, China, Bangladesh, and a few countries in Africa. In the present study, in vitro anti-radical and antidiabetic potential of isolated fractions of methanolic extract of C. viscosa whole plant (MeCV) has been investigated. The identification of polyphenols and their related functional groups in the bioactive fraction was categorized by using HPLC and FT-IR.

Results: The total phenolic and flavonoid contents of F-D were higher than those of F-A, F-B, and F-C. The F-D exhibited superior antioxidant capacity when compared with the remaining three fractions. However, the F-D showed the highest glucose diffusion activity over the $30 \mathrm{~min}-27 \mathrm{~h}$ incubation period and also inhibited both aglucosidase and a-amylase enzyme activity. HPLC analysis revealed the presence of the two known compounds (protocatechuic acid hexoside, rutin) and six unknown compounds in the F-D. FTIR spectrum confirmed the presence of phenol group.

Conclusion: The isolated F-D obtained from MeCV displayed superior antioxidant and antidiabetic activity which indicate the presence of polyphenols in the fraction. The data findings of the present study support the traditional uses of the whole plant of $C$. viscosa as a promising natural source of biological medicines for oxidative stress and diabetes.
\end{abstract}

Keywords: Cleome viscosa, Isolated fractions, Antioxidant activity, Antidiabetic activity, HPLC, Polyphenols

\section{Background}

Diabetes is rapidly spreading and resulting in the death of around 4 million by the year of 2017 in Europe, Middle East, North Africa, North America, Caribbean, South and Central America, South East Asia, and Western Pacific countries [1]. About $90 \%$ of all cases of diabetes in these countries are noninsulin-dependent diabetes mellitus (NIDDM), also known as type-2 diabetes (T2D). This

\footnotetext{
* Correspondence: drsrr2017@gmail.com

'Division of Ethnopharmacology, Department of Biotechnology, School of Herbal studies and Naturo Sciences, Dravidian University, Kuppam, Andhra Pradesh 517426, India

Full list of author information is available at the end of the article
}

could be because of lifestyle and dietary prospects, such as physical inactivity, smoking, consumption of alcohol, and lesser consumption of vegetables, fruits, and natural products [2]. NIDDM is also complicated by insulin conflict, hyperinsulinemia, impede insulin discharge, glucose uptake, and utilization [3]. Thus, so many factors make diabetes a significant medical issue which requires a search for other viable and safe enzyme inhibitors from natural medicine to treatment of diabetes.

In enterocytes of the small intestine, carbohydrate can be absorbed only as monosaccharides (glucose and fructose). Pancreatic $\alpha$-amylase (E.C. 3.2.1.1) is the major enzyme in the digestive system and it catalyzes the 
hydrolysis of starch and various oligosaccharides into low-molecular-weight products such as glucose, maltose, and maltotriose units [4]. $\alpha$-Glucosidase catalyzes the hydrolysis of starch to simple sugars like glucose for intestinal absorption which in turn leads to an increase in blood glucose levels. Thus, resulting in higher postprandial blood glucose levels [5]. This process of dietary starch digestion takes place quickly and results in a postprandial rise in blood sugar. The higher in postprandial blood glucose level is related to the $\alpha$-amylase and $\alpha$ glucosidase action of the small intestine [6]. Therefore, inhibition of these two enzymes could play a role in controlling diabetes by hindering the absorption of starch and expanding intestinal sugar holding time. The rate of glucose absorption declines by inhibiting $\alpha$-amylase and $\alpha$-glucosidase action and resulting decrease in the rate of increment of postprandial blood glucose levels [7]. Thus, the retardation of the action of $\alpha$-amylase and $\alpha$ glucosidase by any inhibitors may be one of the most effective approaches to control NIDDM [8]

Several antidiabetic medicines, for example acarbose, voglibose, and miglitol, may lessen the ingestion rate of glucose by hindering sugar processing, causing a decline in postprandial serum glucose [9]. However, a good number of these synthetic hypoglycemic specialists are toxic in addition to cause side effects [10]. A part of these side effects integrates the inflammation of gastrointestinal, distress of stomach, and looseness of the bowels and tooting $[11,12]$. An alternative methodology like the incorporation of natural foods in the diet may show viable inhibitory action against $\alpha$-glucosidase and $\alpha$-amylase with lesser side effects. Various therapeutic plants have indicated some relationship to the hindrance of starch handling catalysts $[13,14]$.

Oxidative stress is an important issue faced by several diabetics which is caused due to overproduction of reactive oxygen species (ROS) such as hydrogen peroxide $\left(\mathrm{H}_{2} \mathrm{O}_{2}\right), \mathrm{O}_{2}^{-} \cdot$ and $\mathrm{OH} \bullet$ [15]. These ROS are responsible for the damage of most of the biomolecules such as lipids, proteins, and DNA and also cause the death of cell [16]. Plant components can be utilized to control the steadiness between free radicals and antioxidants and might be a lesser harmful choice when compared to synthetic antioxidants [17]. Due to several harmful side effects caused by synthetic antioxidants, the contemporary world is now looking for the potentially safe therapeutic plants in the treatment of several oxidative stressrelated diseases.

Consequently, a few contemporary studies have been focused on the finding of promising novel antioxidants, fundamentally phenolics, and flavonoids from natural resources, which have similar properties and less-toxic impact having obvious biological actions. Plants have standard antioxidant properties of antioxidants, which arrange a good agreement of compounds, for example, a few classes of flavonoids (anthocyanins, flavonols, and flavones) and non-flavonoids (phenolic acids, lignins, terpenoids and stilbenes, and so on). These compounds are unlike in structure, the amount of phenolic hydroxyl groups, and their position is important to deviation in their antioxidative and biological actions [18]. Herbs and vegetables reach in antioxidant agents and extra phytochemicals are able to delay oxidative pressure and the other related issues [19]. The extraction, separation of the bioactive compound, pharmacological screening, toxicological assessment, and clinical assessments are the important steps involved in an evaluation of any biologically active compound from the plant resources. Hence, the present research work is also designed in the same manner involving sequential steps such as extraction, isolation, and separation of bioactive compound from plants extracts by widespread phytochemical screening assay, chromatographic techniques, such as column, thin-layer chromatography (TLC), high-performance liquid chromatography (HPLC), and also study of biological activities by in vitro methods.

In this present work, we have selected the traditional medicinal plant namely Cleome viscosa. L, which is commonly known as Asian spider flower or Yellow spider flower and locally known as "Bagra" in Hindi. It is spread all over the major parts of Asia, Africa, North America, South America, and Australia nations. In Indian Ayurvedic and Chinese medicine system, it is considered as an important traditional medicine for malaria, hypertension, rheumatic arthritis, neurasthenia, and snake bite [20]. Various researchers have documented for anti-inflammatory, hepatoprotective, and hypoglycemic activities of C. viscosa plant various extracts $[21,22]$. Therefore, the present study is aimed to evaluate the preliminary phytochemical screening, estimation of total phenolic and flavonoid content, in vitro antioxidant activity, and in vitro antidiabetic activity of isolated pooled fractions obtained from $\mathrm{MeCV}$.

\section{Methods \\ Chemicals and reagents}

The chemicals and standards were obtained from Himedia and Sigma-Aldrich (Bangalore, India). All other reagents, polar, and non-polar solvents were used for an analytical grade. Merck grade Aluminum TLC plate (silica gel coated with fluorescent indicator F254) size $20 \times 20 \mathrm{~cm}$ were used for thin-layer chromatography. Column $(60 \mathrm{~cm}$ height $\times 5 \mathrm{~cm}$ diameter $)$ and silica gel (60-120 mesh) were used for column chromatography.

\section{Collection of plant material and extraction}

The well-grown and healthy Cleome viscosa whole plant material was collected, shade dried, and powdered. The 
powder was used for the extraction of the bioactive compounds into methanol solvent. The dried powder material $(500 \mathrm{~g})$ was extracted in $5 \mathrm{~L}$ methanol using a Soxhlet apparatus at ambient temperature for $72 \mathrm{~h}$. Later, the extract was filtrated under vacuum, concentrated in a rotary evaporator, and then lyophilized. Then, the obtained crude methanolic extract $(\mathrm{MeCV})$ was used for the fractionation [23].

\section{Preliminary phytochemical screening of MeCV}

Gibbs method [24] was used to analyze phenols, steroids, alkaloids, and lignin; Peach and Tracey method was adapted for flavonoids analysis; Trease and Evans procedure [25] was used for tannins screening; Kokate method [26] was used for glycosides analysis; Rizk method [27] was adopted to saponins, quinines, and coumarins screening; and Trim-Hill reagent test for terpenoids screening of $\mathrm{MeCV}$.

\section{Isolation process}

\section{Fractionation of the MeCV by column chromatography}

The $60 \times 5 \mathrm{~cm}$ column was used to elute components from MeCV based on the Khoo et al. (2015) method [28]. The column was rinsed by hexane and dried before exercise. The column was filled with $3 / 4^{\text {th }}$ of $n$-hexane and $2 / 3^{\text {rd }}$ of silica gel. The packing silica gel was utilized subsequently for activating at $100{ }^{\circ} \mathrm{C}$ for $1 \mathrm{~h}$ by using hexane. The column was run through various solvent combinations like 80\%:20\%; 60\%:40\%; 40\%:60\%; 20\%:80\% of methanol:n-hexane, methanol:ethyl acetate, and methanol:aqueous along with 100\% methanol (me), $100 \%$ aqueous (aq), $100 \%$ ethyl acetate (ea), and $100 \%$ hexane (nh) combinations were also utilized, after loading with $\mathrm{MeCV}(20 \mathrm{~g})$ in the activated silica gel $(30 \mathrm{~g})$. Further, $1 \mathrm{~mL} / \mathrm{min}$ flow rate was maintained at collected fractions and every fraction was concentrated using a rotary evaporator under reduced pressure and we were calculating the percentage of yielding of fractions by using $\mathrm{R} / \mathrm{S} \times 100(R=$ weight of obtained fractions residues; $S$ = weight of test sample used) formula.

\section{Thin layer chromatographic study}

As per the usual basic climbing manner, we were using 60F254 (Merck), $7 \times 6 \mathrm{~cm}$ pre-coated TLC plates. We cut TLC plate on $1 \mathrm{~cm}$ between two tracks by ordinary household scissors based on the plate markings. Capillary tubes were used to spot the sample $(1 \mu \mathrm{L})$. Hexane: ethyl acetate:acetic acid (2:7:1 ratio) solvent system was utilized [29]. Spot the fractions on TLC plate and developed in TLC chamber. After developing the plates to allow the air dry in addition to spray the iodine vapors to detect the bands. After its retention, factor $\left(R_{\mathrm{f}}\right)$ values were calculated as follows:

$$
R_{\mathrm{f}}=\frac{\text { Distance travelled by the solute }}{\text { Distance travelled by the solvent }}
$$

\section{Determination of phytochemical content in the isolated pooled fractions of MeCV \\ Total content of phenols}

Total phenolic content (TPC) was calculated according to the standard Singleton and Rossi (1965) procedure [30]. Then, $100 \mathrm{mg} / \mathrm{mL}$ of isolated pooled fractions of $\mathrm{MeCV}$ was mixed with Folin-Ciocalteu's reagent $(0.5$ $\mathrm{mL})$ and $20 \%$ of sodium carbonate $(2.5 \mathrm{~mL})$ in addition to $6.0 \mathrm{~mL}$ of distilled water. The resulting solution was mixed well and incubated at $40{ }^{\circ} \mathrm{C}$ for $30 \mathrm{~min}$ by using water bath shaker. The reaction mixture absorbance was measured at $760 \mathrm{~nm}$. A calibration curve was prepared by using gallic acid standard.

\section{Total content of flavonoids}

For the determination of total flavonoid content (TFC), aluminum chloride colorimetric method was employed by using Chang et al. (2002) [31]. The 50-100 mg/mL concentration of quercetin standard was used for the construction of the calibration curve. In brief, $100 \mathrm{mg}$ of isolated pooled fractions of $\mathrm{MeCV}$ was dissolved in $1 \mathrm{~mL}$ of distilled water individually. Further, $0.5 \mathrm{~mL}$ of this solution was mixed with $95 \%$ ethanol $(1.5 \mathrm{~mL}), 10 \%$ aluminum chloride $(0.1$ $\mathrm{mL})$, and $1 \mathrm{M}$ potassium acetate $(0.1 \mathrm{~mL})$ in addition to distilled water $(2.8 \mathrm{~mL})$. After incubation at room temperature $\left(26 \pm 2{ }^{\circ} \mathrm{C}\right)$ for $30 \mathrm{~min}$, the reaction mixture absorbance was measured at $415 \mathrm{~nm}$.

\section{In vitro antioxidant activity of isolated pooled fractions of MeCV DPPH radical scavenging assay}

The antioxidant activity of the isolated pooled fractions of MeCV was measured based on the DPPH free radical scavenging activity according to BrandWilliams et al.'s (1995) method with slight modifications [32]. Three milliliters of $60 \mu \mathrm{M}$ DPPH in methanol was mixed with $1 \mathrm{~mL}$ of isolated pooled fractions from $\mathrm{MeCV}$ of various concentrations (20, 40, 60, 80, and $100 \mu \mathrm{g} / \mathrm{mL}$ ). Consequently, $1 \mathrm{~mL}$ of methanol and $1 \mathrm{~mL}$ of DPPH was used as control and gallic acid was used as a reference standard. The reaction was conceded in three times and the absorbance was measured at $517 \mathrm{~nm}$ after incubation of $30 \mathrm{~min}$ in dark.

\section{ABTS $^{-+}$radical scavenging assay}

The assay of ABTS radical scavenging activity was adopted from Re et al. (1999) [33]. The stock solution included $7 \mathrm{mM}$ of ABTS and $2.4 \mathrm{mM}$ of potassium persulfate. One milliliter of varying concentrations (20, 40, 60,80 , and $100 \mu \mathrm{g} / \mathrm{mL}$ ) of isolated pooled fractions of 
$\mathrm{MeCV}$ and standard ascorbic acid was permitted to react with $1 \mathrm{~mL}$ of ABTS stock solution and the absorbance was measured at $734 \mathrm{~nm}$ after the incubation for $7 \mathrm{~min}$.

\section{Hydrogen peroxide scavenging assay}

The ability of the isolated pooled fractions of $\mathrm{MeCV}$ to scavenge hydrogen peroxide $\left(\mathrm{H}_{2} \mathrm{O}_{2}\right)$ was determined according to the Ruch et al.'s (1989) method [34]. Then, $2 \mathrm{mmol} / \mathrm{l}$ of $\mathrm{H}_{2} \mathrm{O}_{2}$ solution was prepared in neutral phosphate buffer. Isolated pooled fractions $(20,40,60$, 80 , and $100 \mu \mathrm{g} / \mathrm{mL}$ ) were added to $0.6 \mathrm{~mL}$ of $\mathrm{H}_{2} \mathrm{O}_{2}$ solution. The absorbance of $\mathrm{H}_{2} \mathrm{O}_{2}$ was measured at $230 \mathrm{~nm}$ after incubation for 10 min against blank and the radical scavenging activity was compared with ascorbic acid.

\section{Superoxide radical $\left(\mathrm{O}_{2}^{-}\right)$scavenging assay}

Superoxide radicals are generated in phenazine methosulfate (PMS), nicotinamide adenine dinucleotide (NAD) systems by oxidation of nicotinamide adenine dinucleotide and assayed by the reduction of nitroblue tetrazolium (NBT) [35]. In this experiment, the superoxide radicals were generated in $3 \mathrm{~mL}$ of $16 \mathrm{mM}$ Tris $\mathrm{HCl}$ buffer (pH 8.0) containing $1 \mathrm{~mL}$ of $50 \mu \mathrm{M} \mathrm{NBT}, 1 \mathrm{~mL}$ of 7 $8 \mu \mathrm{M}$ NAD, and isolated pooled fractions $(20-100 \mu \mathrm{g} /$ $\mathrm{mL}$ ). The reaction was started by adding $1 \mathrm{~mL}$ of $10 \mu \mathrm{M}$ PMS solution to the mixture. The reaction mixture was incubated at $25{ }^{\circ} \mathrm{C}$ for $5 \mathrm{~min}$; absorbance was measured at $560 \mathrm{~nm}$ using a spectrophotometer against the blank.

\section{Ferric reducing antioxidant power assay}

The ferric reducing antioxidant power (FRAP) assay was conducted according to the method reported by Benzie and Strain [36]. FRAP reagent was prepared freshly by mixing three solutions $\mathrm{a}, \mathrm{b}$, and $\mathrm{c}, 300 \mathrm{mM}$ sodium acetate buffer, $\mathrm{pH}=3.6$ (solution a), $10 \mathrm{mM}$ TPTZ solution in $40 \mathrm{mM} \mathrm{Hcl}$ (solution b), and $20 \mathrm{mM}$ ferric chloride $\left(\mathrm{FeCl}_{3}\right)$ (solution c) in the proportions of 10:1:1 (v/v/v). The reagent was kept in darkness for $30 \mathrm{~min}$ to complete the reaction. For the assay, $0.1 \mathrm{~mL}$ of isolated pooled fractions from $\mathrm{MeCV}$ and ascorbic acid (20-100 $\mu \mathrm{g} / \mathrm{mL}$ ) was mixed with $2.9 \mathrm{~mL}$ of FRAP reagent separately. All the samples were prepared in triplicate and vortexed for $1 \mathrm{~min}$ and incubated in dark for $30 \mathrm{~min}$ at $37{ }^{\circ} \mathrm{C}$. The increase in absorbance of the reaction mixture was measured for each sample on UV-Visible spectrophotometer at $593 \mathrm{~nm}$. FRAP activity was calculated as $\mu \mathrm{M}$ ascorbic acid equivalents (AAE) in a gram of sample dry weight.

\section{In vitro antidiabetic activity of isolated pooled fractions of MeCV}

\section{Inhibition of glucose diffusion method}

A simple model system was used to evaluate the effects of isolated pooled fractions from $\mathrm{MeCV}$ on the movement of glucose in vitro. The model was adapted from a method described by Edwards et al. (1987) [37] which involved the use of a sealed dialysis tube into which $15 \mathrm{~mL}$ of a solution of glucose and sodium chloride $(0.15 \mathrm{M})$ was introduced and the content of glucose in the external solution was measured. The model used in the present experiment consisted of a dialysis tube $(6 \mathrm{~cm} \times 15 \mathrm{~mm})$ into which $1 \mathrm{~mL}$ of $50 \mathrm{~g} / \mathrm{L}$ each fraction in $1 \% \mathrm{CMC}$ and $1 \mathrm{~mL}$ of $0.15 \mathrm{M}$ sodium chloride containing $0.22 \mathrm{M}$ D-glucose was added. The dialysis tube was sealed at each end placed in a 50 $\mathrm{mL}$ centrifuge tube containing $45 \mathrm{~mL}$ of $0.15 \mathrm{M}$ sodium chloride. The tubes were placed on an orbital shaker and kept at room temperature. The movement of glucose into the external solution was monitored at different time intervals (30 min, $1 \mathrm{~h}, 3 \mathrm{~h}, 7 \mathrm{~h}, 24 \mathrm{~h}$, and $27 \mathrm{~h}$ ).

\section{Study of a- Glucosidase inhibition assay}

One milligram of the $\alpha$-glucosidase enzyme (isolated from Saccharomyces cerevisiae) was suspended with 100 $\mathrm{mL}$ neutral PBS buffer which contains the $200 \mathrm{mg}$ of bovine serum albumin [38]. The various concentrations $(20,40,60,80$, and $100 \mu \mathrm{g} / \mathrm{mL})$ of isolated pooled fractions from $\mathrm{MeCV}$ were added with reaction mixture (10 $\mu \mathrm{L}$ of pH 6.8 phosphate buffer; $490 \mu \mathrm{L}$ of $5 \mathrm{mM}$ p-NPG (p-nitro phenyl $\alpha$-d glucopyranoside)). The reaction mixture was incubated at $37^{\circ} \mathrm{C}$ for $5 \mathrm{~min}$ then added 250 $\mu \mathrm{L}$ of $\alpha$-glucosidase $(0.15 \mathrm{unit} / \mathrm{mL})$ and again incubated at $37^{\circ} \mathrm{C}$ for $15 \mathrm{~min}$. Then cool the reaction mixture and add $2 \mathrm{~mL}$ of sodium carbonate $(200 \mathrm{mM})$ to stop the reaction. The activity of enzyme inhibition was measured at $405 \mathrm{~nm}$ and acarbose was utilized as a reference compound.

\section{Study of a-amylase inhibitory assay}

In $1 \%$ phosphate buffer and the starch solution was prepared and incubated with $500 \mu \mathrm{L}$ enzyme ( $\alpha$-amylase) for $10 \mathrm{~min}$ at $37^{\circ} \mathrm{C}$. Then, $1 \mathrm{~mL}$ of $(20,40,60,80$, and $100 \mu \mathrm{g} / \mathrm{mL}$ ) isolated pooled fractions from $\mathrm{MeCV}$ was added to the enzyme solution. Further, $2 \mathrm{M}$ of $\mathrm{NaOH}$ is applied to stop the reaction process. One milliliter of $\mathrm{Di}$ nitro salicylic acid is mixed and the reaction is maintained in the hot water bath for 5 min. After completion of incubation, test tubes were cooled by running tap water, and the final volume of test solution was to make up to $10 \mathrm{~mL}$ using sterile distilled water and absorbance was measured at $540 \mathrm{~nm}$. Acarbose was used as a reference substance [39].

\section{Percentage calculation}

Percentage of free radical scavenging and $\alpha$-amylase and $\alpha$-glucosidase inhibition was measured by using the following formula: \% Inhibition/ scavenging activity = $\left[\left(A_{\text {control }}-A_{\text {sample }}\right) /\left(A_{\text {control }}\right)\right] \times 100$ where $A=$ absorbance 


\section{Characterization of active F-D fraction Identification of phenolic and flavonoids by high- performance liquid chromatography}

Instrumentation Twofold Waters 600 E pump equipped the system with Waters-2996 photodiode array detector linked to arrangement processor was used for the analysis. A maximum force of 2500 psi and minimum of 1500 psi was retained. C18 column Symmetry $(250 \times 4.6)$ was used in chromatographic separation at $25^{\circ} \mathrm{C}$.

Chromatographic conditions In this analysis, two types of solvents were prepared, i.e., solvent-A (mobile phase: acetonitrile) and solvent-B (water with $0.2 \%$ formic acid). The stream velocity was held in reserve at $0.7 \mathrm{~mL} / \mathrm{min}$. The ascent series was as pursued: $35 \% \mathrm{~A} / 65 \% \mathrm{~B}$ at $0-6$ min, $60 \% \mathrm{~A} / 40 \% \mathrm{~B}$ at $6-9 \mathrm{~min}, 80 \% \mathrm{~A} / 20 \% \mathrm{~B}$ at $9-14$ $\mathrm{min}, 100 \% \mathrm{~A}$ at $14-25 \mathrm{~min}$, and $35 \% \mathrm{~A} / 65 \% \mathrm{~B}$ at $25-30$ min. The $20 \mu \mathrm{L}$ was considered as injection volume and peaks were scrutinized at $280 \mathrm{~nm}$. Peaks were identified by congruent retention times (RT) compared with previously reported standards.

Identification of functional groups by Fourier transform infrared The Fourier transform infrared (FTIR) spectra of purified isolated fractions powder were recorded on a Thermo Nicolet 330 FTIR spectroscopy (Madison, WI, USA). To find good indicators to resonance percentage, isolated fractions were taken in the range $400-4000 \mathrm{~cm}^{-1}$ and the resolution was kept as 4.0 $\mathrm{cm}^{-1}$.

Statistical analysis All investigation values were represented mean \pm SE and mean \pm SD. The data was investigated by one-way ANOVA followed by Tukey's post hoc and Dunnett's test (SPSS version 16.0, SPSS Inc. Chicago, IL, USA). The dose-response curves were plotted between the percentages of scavenging activity versus concentrations.

\section{Results}

\section{Preliminary phytochemical screening of MeCV}

In the view of extraction outcome, the yield of $\mathrm{MeCV}$ was $18.6 \% \mathrm{w} / \mathrm{w}$ with the weight of $93 \mathrm{~g}$. The results obtained from the preliminary phytochemical tests are represented in Table 1 . The study showed the presence of flavonoids, phenols, steroids, alkaloids, lignin, tannins, glycosides, terpenoids, saponins, quinines, and coumarins in the MeCV.

\section{Analysis of column chromatography}

We have collected 16 purified fractions from the isolation and purification process of $\mathrm{MeCV}$ by using column
Table 1 Preliminary phytochemical screening of MeCV

\begin{tabular}{|c|c|c|}
\hline \multicolumn{2}{|c|}{ Phytochemicals } & \multirow{2}{*}{$\frac{\mathrm{MeCV}}{+}$} \\
\hline Flavonoids & Ferric chloride test & \\
\hline & Shinoda's test & + \\
\hline & Zinc-Hcl reduction test & + \\
\hline & Lead-acetate test & + \\
\hline \multirow[t]{2}{*}{ Phenols } & Phenols test & + \\
\hline & Ellagic acid test & + \\
\hline \multirow[t]{2}{*}{ Steroids } & Salkowski test & + \\
\hline & Liebermann-burchard & + \\
\hline \multirow[t]{3}{*}{ Alkaloids } & Mayer's test & - \\
\hline & Wagner's test & + \\
\hline & Dragendorff's test & + \\
\hline \multirow[t]{2}{*}{ Lignin } & Labat test & + \\
\hline & Lignin test & - \\
\hline \multirow[t]{2}{*}{ Tannins } & Ferric chloride test & + \\
\hline & Lead acetate test & + \\
\hline \multirow[t]{3}{*}{ Glycosides } & Kellarkiliani test & - \\
\hline & Conc. $\mathrm{H}_{2} \mathrm{SO}_{4}$ test & + \\
\hline & Moisch's test & + \\
\hline Terpenoids & Trim- hill reagent test & + \\
\hline \multicolumn{2}{|l|}{ Saponins } & + \\
\hline \multicolumn{2}{|l|}{ Quinines } & + \\
\hline \multicolumn{2}{|l|}{ Coumarins } & + \\
\hline
\end{tabular}

$+=$ presence; $-=$ absence

chromatography. The collected fractions were all concentrated by using rotary evaporation $(100 \mathrm{rpm})$ at $40{ }^{\circ} \mathrm{C}$ (H-Biomedical-EV311 plus-v). After completion of this process, we collected semi-solid and solid material and describe the color and yield (in g) of fractions. Percentage of yielding values of the isolated fractions was represented in Table 2.

\section{Thin layer chromatographic analysis}

Table 3 describes the retention factor $\left(R_{\mathrm{f}}\right)$ values of all 16 fractions. The similar fractions were pooled into four main categories (F-A, F-B, F-C, and F-D) based on their $R_{\mathrm{f}}$ values. The pooled F-A, F-B, F-C, and F-D fractions were tested for total phenolic, total flavonoid content, in vitro antioxidant, and in vitro antidiabetic activity.

\section{Determination of phytochemicals content in isolated pooled fractions of MeCV}

In our current results, F-D demonstrates the high content of TCP (104.89 $\pm 4.52 \mathrm{mg} \mathrm{GAE} / \mathrm{g})$ and TCF $(97.35 \pm 2.81 \mathrm{mg} \mathrm{QRE} / \mathrm{g})$ when compared to the rest of the fractions. At that same time, F-A demonstrates the low content of TCP $(33.77 \pm 0.69 \mathrm{mg} \mathrm{GAE} / \mathrm{g})$ and TCF $(38.28 \pm 1.36 \mathrm{mg} \mathrm{QRE} / \mathrm{g})$. TCP content has 
Table $2 \mathrm{MeCV}$ isolated fractions extractive values

\begin{tabular}{|c|c|c|c|c|}
\hline Number of fraction collected & Solvents used & Color appearance & Yielding (in g) & Yielding Percentage (\%w/w) \\
\hline 1-Fraction & Me : Nh (80:20) & Light green & 2.244 & 11.22 \\
\hline 2-Fraction & Me : Nh (60:40) & Light green & 1.852 & 9.26 \\
\hline 3-Fraction & Me : Nh (40:60) & Light green & 1.097 & 5.48 \\
\hline 4-Fraction & Me : Nh (20:80) & Light green & 1.784 & 8.92 \\
\hline 5-Fraction & Me :Ea (80:20) & Light brown & 1.730 & 8.65 \\
\hline 6-Fraction & Me :Ea (60:40) & Light brown & 2.033 & 10.16 \\
\hline 7-Fraction & Me :Ea (40:60) & Light brown & 2.725 & 13.62 \\
\hline 8-Fraction & Me :Ea (20:80) & Light brown & 2.423 & 12.11 \\
\hline 9-Fraction & Me :Aq (80:20) & Dark brown & 3.594 & 17.97 \\
\hline 10-Fraction & $\mathrm{Me}: \mathrm{Aq}(60: 40)$ & Dark brown & 3.157 & 15.78 \\
\hline 1-1Fraction & Me :Aq (40:60) & Dark brown & 3.468 & 17.34 \\
\hline 12-Fraction & Me :Aq (20:80) & Dark brown & 3.541 & 17.70 \\
\hline 13-Fraction & Me-100\% & Brown & 3.615 & 18.07 \\
\hline 14-Fraction & Aq-100\% & Dark brown & 3.600 & 18.00 \\
\hline 15-Fraction & Ea-100\% & Light brown & 3.568 & 17.84 \\
\hline 16-Fraction & Nh-100 \% & Light green & 3.347 & 16.73 \\
\hline
\end{tabular}

Me methanol, $\mathrm{Nh} \mathrm{n}$-hexane, $\mathrm{Ea}$ ethyl acetate, $\mathrm{Aq}$ aqueous

rich source than TCF in all fractions (Fig. 1). TCP was calculated by standard gallic acid equation curve, i.e., $Y=3.536 x+0.496 ; R^{2}=0.997$ and TCF was calculated by standard quercetin equation curve, i.e., $Y=$ $2.950 x+0.997 ; R^{2}=0.983$.

Table $3 R_{f}$ values and number of spots detected of MeCV isolated fractions

\begin{tabular}{lll}
\hline Name of fraction & No. of spots detected & $\boldsymbol{R}_{\mathrm{f}}$ values \\
\hline 1-Fraction & 02 & $0.96,0.20$ \\
2-Fraction & 04 & $0.90,0.86,0.34,0.32$ \\
3-Fraction & 04 & $0.90,0.86,0.34,0.32$ \\
4-Fraction & 04 & $0.90,0.86,0.34,0.32$ \\
5-Fraction & 02 & $0.88,0.18$ \\
6-Fraction & 04 & $0.88,0.86,0.20,0.18$ \\
7-Fraction & 04 & $0.88,0.86,0.20,0.18$ \\
8-Fraction & 03 & $0.88,0.20,0.16$ \\
9-Fraction & 03 & $0.80,0.17,0.15$ \\
10-Fraction & 04 & $0.80,0.77,0.17,0.15$ \\
11-Fraction & 04 & $0.80,0.77,0.17,0.15$ \\
12-Fraction & 03 & $0.77,0.17,0.15$ \\
13-Fraction & 04 & $0.83,0.27,0.26,0.22$ \\
14-Fraction & 05 & $0.85,0.83,0.27,0.26,0.22$ \\
15-Fraction & 05 & $0.85,0.83,0.27,0.26,0.22$ \\
16-Fraction & 05 & $0.85,0.83,0.27,0.26,0.22$ \\
\hline
\end{tabular}

In vitro antioxidant activity of isolated pooled fractions of $\mathrm{MeCV}$

\section{$D P P H$ radical scavenging activity}

In the current study, $\mathrm{MeCV}$ isolated pooled fractions (F-A, F-B, F-C, and F-D) showed considerable movement in the scavenging of DPPH, reaching up to $85 \%$, $85.95 \%, 82.02 \%$, and $82.5 \%$ at $100 \mu \mathrm{g} / \mathrm{mL}$ concentration. Figure 2a demonstrates the dose-response curve of DPPH scavenging activity of four fractions when compared with gallic acid. The $\mathrm{IC}_{50}$ of F-D was 38.54 $\pm 0.36 \mu \mathrm{g} / \mathrm{mL}$ while the $\mathrm{IC}_{50}$ values of gallic acid standard, F-A, F-B, and F-C were $34.47 \pm 0.81 \mu \mathrm{g} /$ $\mathrm{mL}, 47.16 \pm 1.02 \mu \mathrm{g} / \mathrm{mL}, 44.35 \pm 0.47 \mu \mathrm{g} / \mathrm{mL}$, and $40.36 \pm 0.96 \mu \mathrm{g} / \mathrm{mL}$ (Fig. 3). The DPPH scavenging assay is one of the regularly used important methods to scrutinize the presence of antioxidant compounds in plant and plant-based ingredients. The results revealed that the F-D showed potential DPPH scavenging activity when compared to the rest of the fractions.

\section{ABTS radical scavenging activity}

The MeCV isolated F-A, F-B, F-C, and F-D fractions were rapid and efficient scavengers of ABTS (Fig. 2b) and this was validated by the ascorbic acid standard. It exhibited potent scavenging effect against those of ABTS radicals with an $\mathrm{IC}_{50}$ values of F-A $(39.73 \pm 0.70 \mu \mathrm{g} /$ $\mathrm{mL})$, F-B $(35.69 \pm 0.25 \mu \mathrm{g} / \mathrm{mL}), \mathrm{F}-\mathrm{C}(32.18 \pm 0.10 \mu \mathrm{g} /$ $\mathrm{mL})$, and F-D (30.31 $\pm 0.54 \mu \mathrm{g} / \mathrm{mL})$ (Fig. 3). F-D was exhibited high potent scavenging effect significantly 


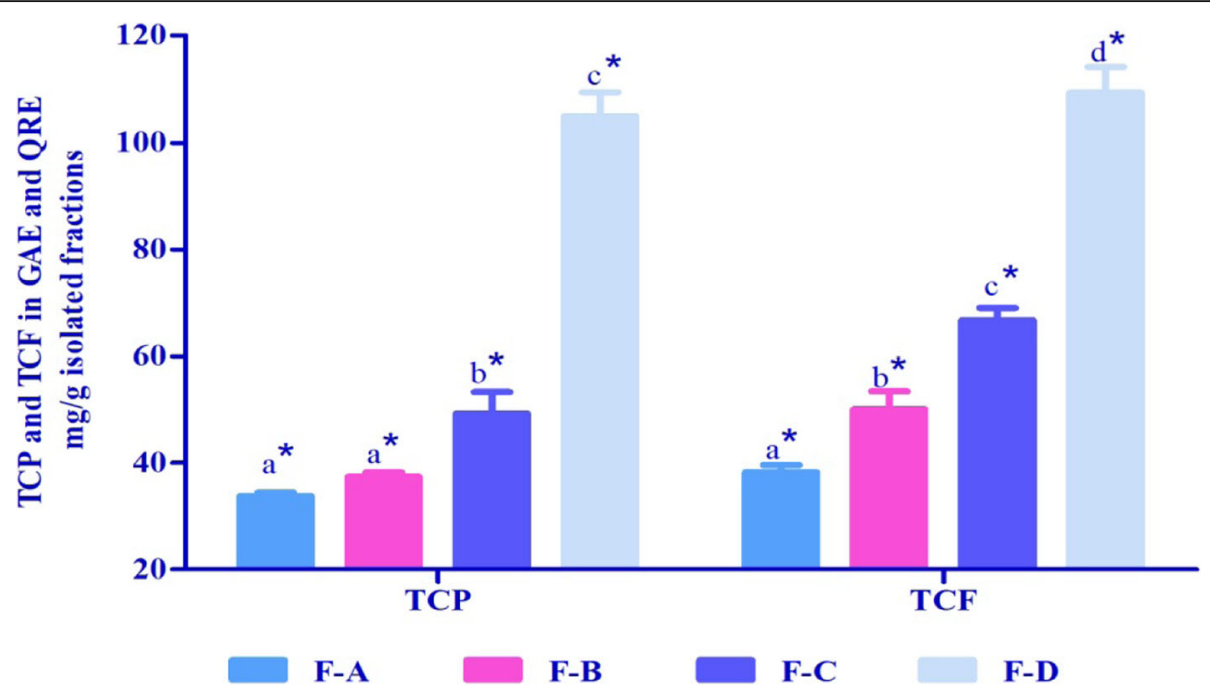

Fig. 1 TCP and TCF in the isolated pooled fractions of MeCV. Each vertical bar represents Mean \pm SE for $n=3$. The vertical bars having the same alphabet do not differ significantly, whereas the bars having the different alphabet differ significantly at $P<0.05$ (one-way ANOVA followed by Tukey's post hoc test)

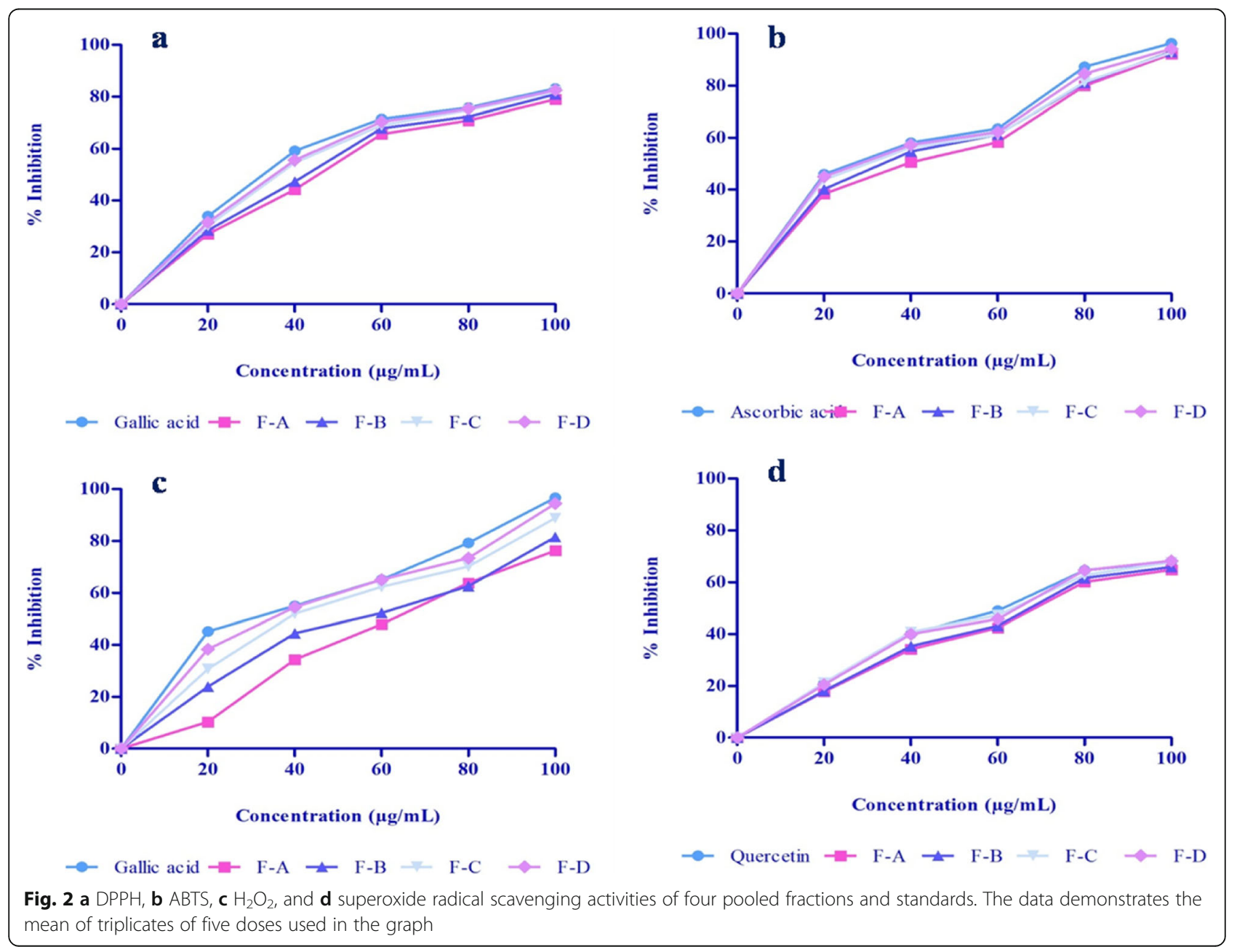




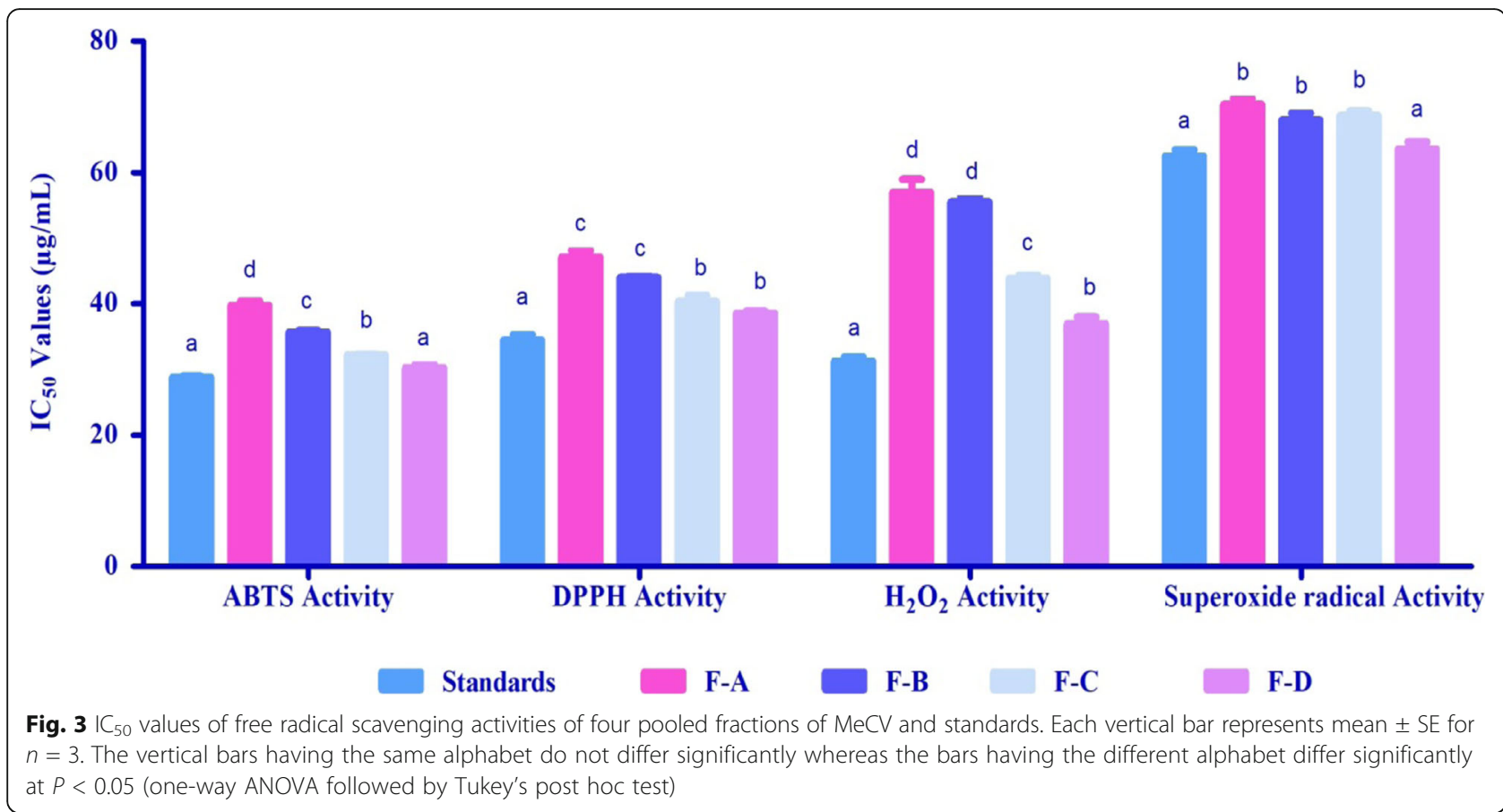

equivalent to that of ascorbic acid $(28.87 \pm 0.15 \mu \mathrm{g} / \mathrm{mL})$. The ABTS scavenging activity percentage was $92.24 \%$ (F-A), 93.02\% (F-B), 92.82\% (F-C), and 94.18\% (F-D) at $100 \mu \mathrm{g} / \mathrm{mL}$ concentration, while ascorbic acid at the similar dose exhibited $96.41 \%$ scavenging.

\section{$\mathrm{H}_{2} \mathrm{O}_{2}$ scavenging activity}

As shown in Figs. $2 \mathrm{c}$ and $3, \mathrm{MeCV}$ isolated F-A, F-B, F$\mathrm{C}$, and F-D also verified the activity of corrosion of $\mathrm{H}_{2} \mathrm{O}_{2}$ in concentration-dependent manner with $76.26 \%$, $81.56 \%, 88.88 \%$, and $94.44 \%$ respectively at $100 \mu \mathrm{g} / \mathrm{mL}$ concentration, while gallic acid was $96.71 \%$ at the same concentration. The $\mathrm{IC}_{50}$ values of corrosion of $\mathrm{H}_{2} \mathrm{O}_{2}$ activity of F-A, F-B, F-C, and F-D were $57.59 \pm 2.91 \mu \mathrm{g} /$ $\mathrm{mL}, 55.52 \pm 0.86 \mu \mathrm{g} / \mathrm{mL}, 43.84 \pm 0.48 \mu \mathrm{g} / \mathrm{mL}$, and 37.60 $\pm 1.36 \mu \mathrm{g} / \mathrm{mL}$ while the standard gallic acid was $31.27 \pm$ $0.65 \mu \mathrm{g} / \mathrm{mL}$. The $\mathrm{H}_{2} \mathrm{O}_{2}$ scavenging activity by the MeCV isolated pooled fractions may be due to their polyphenols, which could be due to the electron transfer to $\mathrm{H}_{2} \mathrm{O}_{2}$ resulting in the formation of $\mathrm{H}_{2} \mathrm{O}$.

\section{Superoxide radical scavenging activity}

In the current assay, the MeCV isolated pooled F-A, F-B, F-C, and F-D was studied for its inhibitory effects on the formation of superoxide radicals. Figure $2 \mathrm{~d}$ exemplifies a significant decrease in the formation of superoxide radicals due to the scavenging knack of pooled fractions and quercetin standard. The F-A, F-B, F-C, and F-D showed the maximum inhibitory capacity of $64.75 \%, 65.85 \%$, $67.68 \%$, and $68.28 \%$ respectively at $100 \mu \mathrm{g} / \mathrm{mL}$, while quercetin standard at the same dose demonstrates $67.94 \%$.
This assay revealed that the isolated fractions have a significant potent (in particularly F-D) scavenging property of superoxide radicals. In contrast, $\mathrm{IC}_{50}$ values of $\mathrm{F}-\mathrm{A}, \mathrm{F}-\mathrm{B}$, F-C, F-D, and quercetin were $70.35 \pm 0.95 \mu \mathrm{g} / \mathrm{mL}, 68.53 \pm$ $0.68 \mu \mathrm{g} / \mathrm{mL}, 68.65 \pm 0.71 \mu \mathrm{g} / \mathrm{mL}, 63.61 \pm 1.04 \mu \mathrm{g} / \mathrm{mL}$, and $62.54 \pm 0.92 \mu \mathrm{g} / \mathrm{mL}$ (Fig. 3). The results indicated that the F-D was significantly as potent as quercetin standard.

\section{Ferric reducing antioxidant power}

The ferric reducing antioxidant ability of the isolated pooled fractions indicated good ferric reducing antioxidant power (FRAP) activity. Among the pooled fractions, the highest FRAP activity was noted for F-D (584.58 \pm $9.15 \mu \mathrm{mol} \mathrm{AAE} / \mathrm{g} \mathrm{DW})$ followed by F-A (229.21 \pm 2.77 $\mu \mathrm{mol}$ AAE/g DW), F-B (346.11 $\pm 4.91 \mu \mathrm{mol}$ AAE $/ \mathrm{g}$ $\mathrm{DW})$, and F-C (495.11 $\pm 6.10 \mu \mathrm{mol} \mathrm{AAE} / \mathrm{g} \mathrm{DW})$ (Fig. 4). According to these results, F-A had significantly $(P<$ 0.05 ) lower FRAP activity. The activity of FRAP was calculated by standard ascorbic acid equation curve, i.e., $Y=0.005 x+0.282 ; R^{2}=0.975$.

\section{In vitro antidiabetic activity of isolated pooled fractions of $\mathrm{MeCV}$ Inhibition of glucose diffusion}

The inhibition rate of glucose diffusion was established to increase from $30 \mathrm{~min}$ to $27 \mathrm{~h}$. After $27 \mathrm{~h}$, the control group showed $403.33 \pm 5.20 \mathrm{mg} / \mathrm{dL}$ in the external glucose solution while F-A, F-B, F-C, and F-D showed $273.33 \pm 2.60 \mathrm{mg} / \mathrm{dL}, 259 \pm 3.21 \mathrm{mg} / \mathrm{dL}, 229.67 \pm 3.48$ $\mathrm{mg} / \mathrm{dL}$, and $219.33 \pm 4.33 \mathrm{mg} / \mathrm{dL}$ respectively (Fig. 5 ). At the all-time intervals, i.e., $30 \mathrm{~min}, 60 \mathrm{~min}, 3 \mathrm{~h}, 7 \mathrm{~h}, 24 \mathrm{~h}$, 


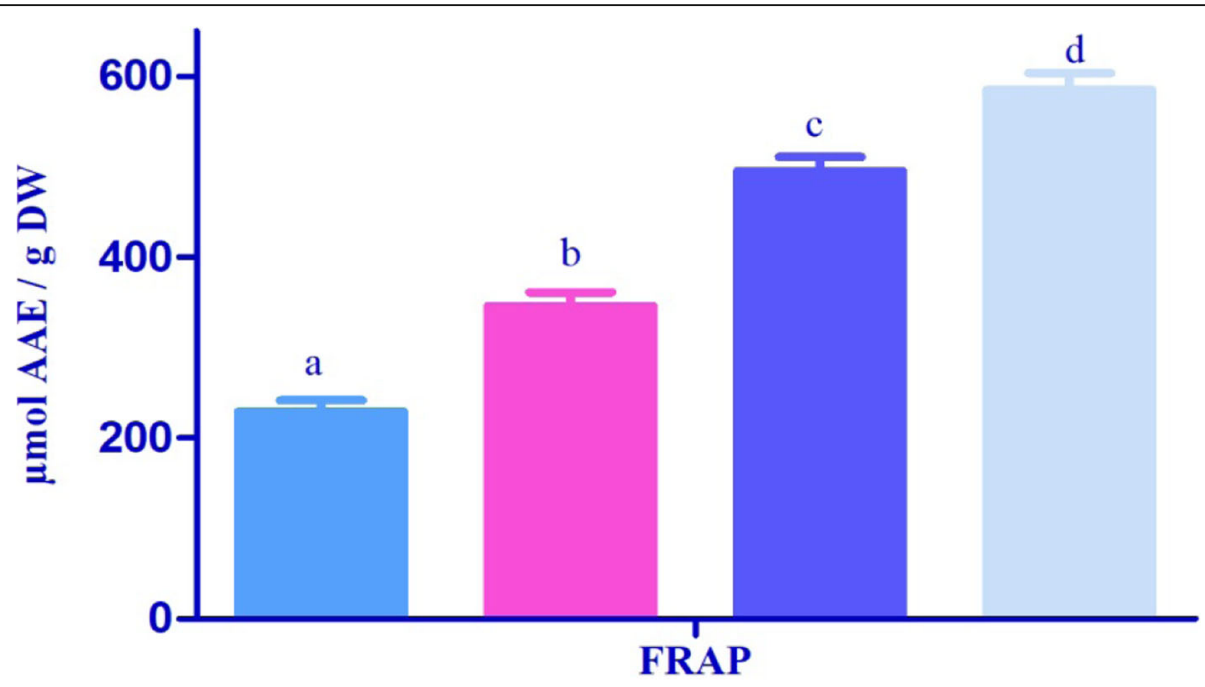

\section{$\begin{array}{lllll}\text { F-A } & \text { F-B } \square \text { F-C } \square \text { F-D }\end{array}$}

Fig. 4 FRAP activity in the isolated pooled fractions of MeCV. Each vertical bar represents mean \pm SE for $n=3$. The vertical bars having the same alphabet do not differ significantly, whereas the bars having the different alphabet differ significantly at $P<0.05$ (one-way ANOVA followed by Tukey's post hoc test)

and 27 h, F-D was showed 127.77\%, 189.04\%, 140.69\%, $119.03 \%, 83.56 \%$, and $83.89 \%$ of maximum GDRI while F-A was showed 73.43\%, 84.66\%, 77.65\%, 56.25\%, $45.06 \%$, and $47.56 \%$ of less GDRI and remaining fractions demonstrated moderate GDRI percentage at the same time intervals (Fig. 6).

\section{Inhibitory effects of carbohydrate-metabolizing enzymes}

The carbohydrate-metabolizing enzymes, i.e., $\alpha$-glucosidase and $\alpha$-amylase, inhibitory strength of $\mathrm{MeCV}$ isolated $\mathrm{F}-\mathrm{A}$, F-B, F-C, and F-D fractions are described in the Fig. 7a, b. The F-D exhibited significantly higher $\alpha$-glucosidase and $\alpha$-amylase inhibition with $\mathrm{IC}_{50} 48.76 \pm 0.96 \mu \mathrm{g} /$

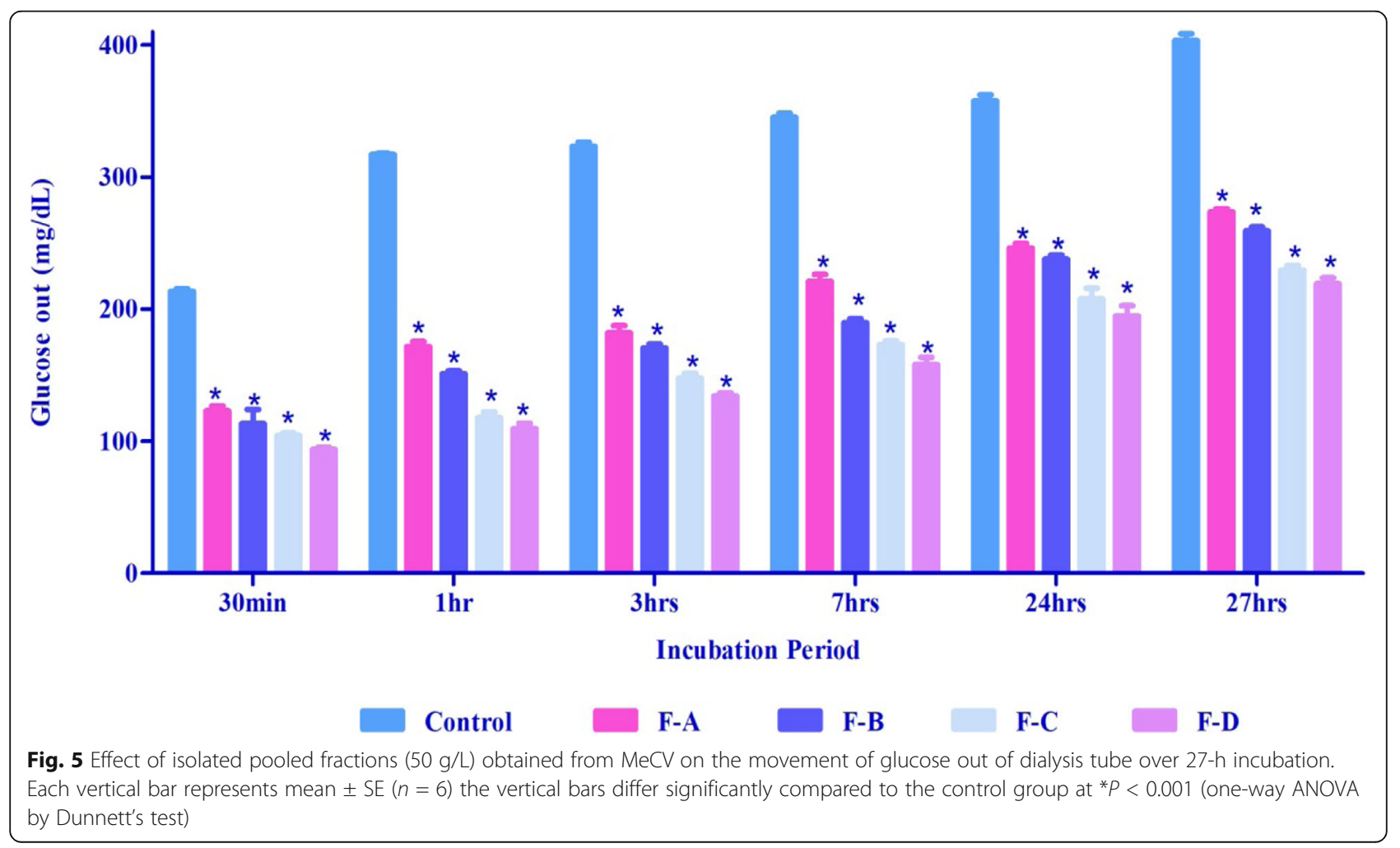




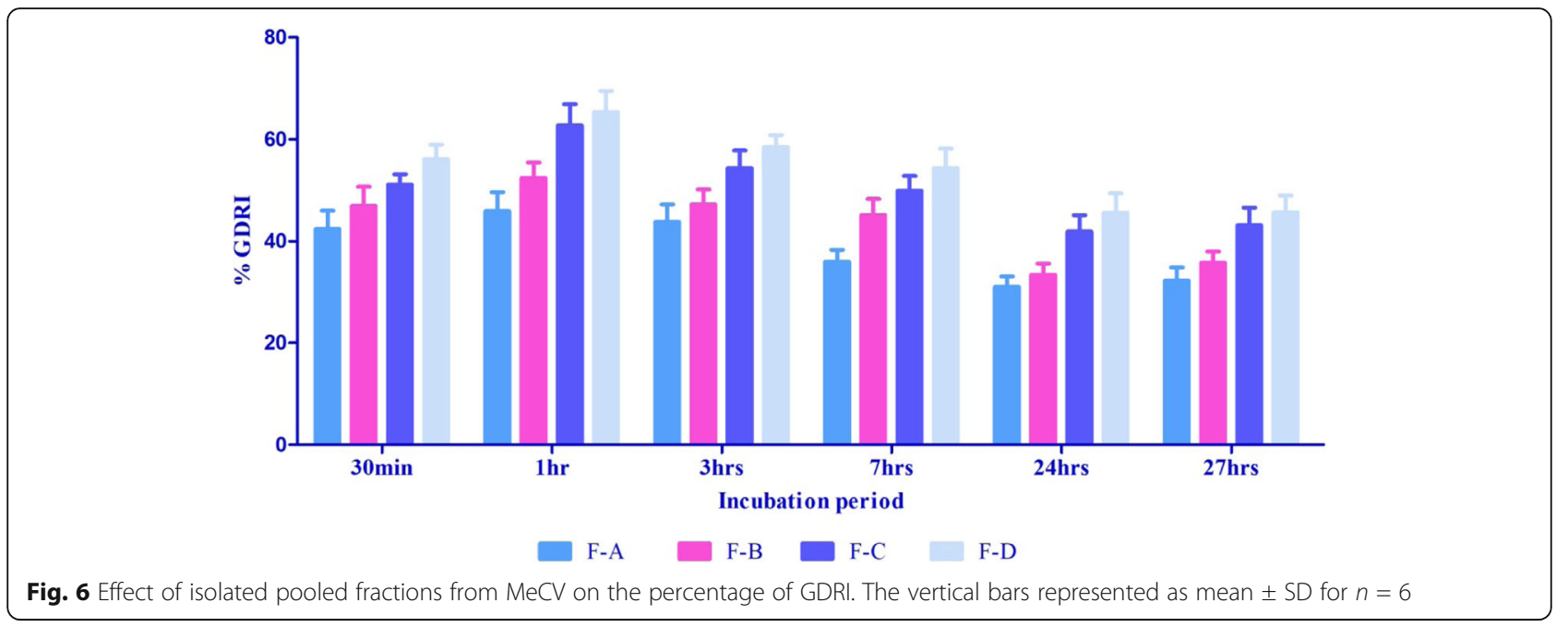

$\mathrm{mL}$ and $25.93 \pm 0.83 \mu \mathrm{g} / \mathrm{mL}$ followed by $\mathrm{F}-\mathrm{A}\left(\mathrm{IC}_{50}\right.$; $105.29 \pm 0.96 \mu \mathrm{g} / \mathrm{mL}$ and $85.56 \pm 0.32 \mu \mathrm{g} / \mathrm{mL}), F-B$ $\left(\mathrm{IC}_{50} ; 104.67 \pm 1.82 \mu \mathrm{g} / \mathrm{mL}\right.$ and $\left.64.54 \pm 0.99 \mu \mathrm{g} / \mathrm{mL}\right)$, and $\mathrm{F}-\mathrm{C}\left(\mathrm{IC}_{50} ; 62.57 \pm 0.58 \mu \mathrm{g} / \mathrm{mL}\right.$ and $38.70 \pm 0.32$ $\mu \mathrm{g} / \mathrm{mL}$ ) were showed lesser and moderate $\alpha$ glucosidase and $\alpha$-amylase inhibition while acarbose $\mathrm{IC}_{50}$ was $21.70 \pm 0.67 \mu \mathrm{g} / \mathrm{mL}$ and $21.43 \pm 0.32 \mu \mathrm{g} / \mathrm{mL}$ (Fig. 8). These results suggest that the F-D has strong $\alpha$-amylase inhibition than $\alpha$-glucosidase enzyme inhibition while F-A has lesser inhibition in both enzymes.

The data demonstrates the mean of triplicates of five doses shown in the graph.

Correlation study of TCP, TCF, in vitro antioxidant activity and in vitro antidiabetic activity

Plant secondary metabolites, in particularly polyphenols, could transform an assortment of enzymes and resistant cells inside the human organization, apart from their potentiality of antioxidants [40]. The Pearson correlation analysis was functionalized to TCP, TCF, DPPH scavenging activity, ABTS radical scavenging activity, $\mathrm{H}_{2} \mathrm{O}_{2}$ scavenging activity, superoxide radical scavenging activity, FRAP, $\alpha$-glucosidase, and $\alpha$-amylase enzyme inhibition activity (Table 4). In F-A, TCP exhibited a nonlinear correlation with TCF, DPPH, ABTS, $\mathrm{H}_{2} \mathrm{O}_{2}$, FRAP, and $\alpha$ glucosidase and a linear correlation with $\mathrm{O}_{2}{ }^{-}$scavenging activity and $\alpha$-amylase enzyme inhibition activity. TCF exhibited a linear correlation in DPPH, ABTS, $\mathrm{H}_{2} \mathrm{O}_{2}, \mathrm{O}_{2}{ }^{-}$, FRAP, and $\alpha$-glucosidase and nonlinear correlation in $\alpha$ amylase enzyme inhibition activity. $\alpha$-Amylase exhibited nonlinear correlation in all activities; at the same moment, $\mathrm{H}_{2} \mathrm{O}_{2}$ exhibited a nonlinear correlation with $\mathrm{O}_{2}{ }^{-}$. A linear correlation was observed in DPPH with ABTS, $\mathrm{H}_{2} \mathrm{O}_{2}, \mathrm{O}_{2}{ }^{-}$, FRAP, and $\alpha$-glucosidase. In linear correlation of ABTS with $\mathrm{H}_{2} \mathrm{O}_{2}, \mathrm{O}_{2}{ }^{-}$, FRAP, $\alpha$-glucosidase. A linear correlation of $\mathrm{H}_{2} \mathrm{O}_{2}$ with $\mathrm{O}_{2}{ }^{-}$, FRAP, $\alpha$-glucosidase, in $\mathrm{O}_{2}{ }^{-}$, with FRAP and $\alpha$-glucosidase along with FRAP was exhibited linear correlation in $\alpha$-glucosidase.

TCP exhibited a non-linear correlation with TCF and FRAP while remaining activities were linearly correlated in F-B. TCF exhibited a linear correlation with $\mathrm{O}_{2}{ }^{-}$and $\alpha$-glucosidase while the rest of the activities exhibited

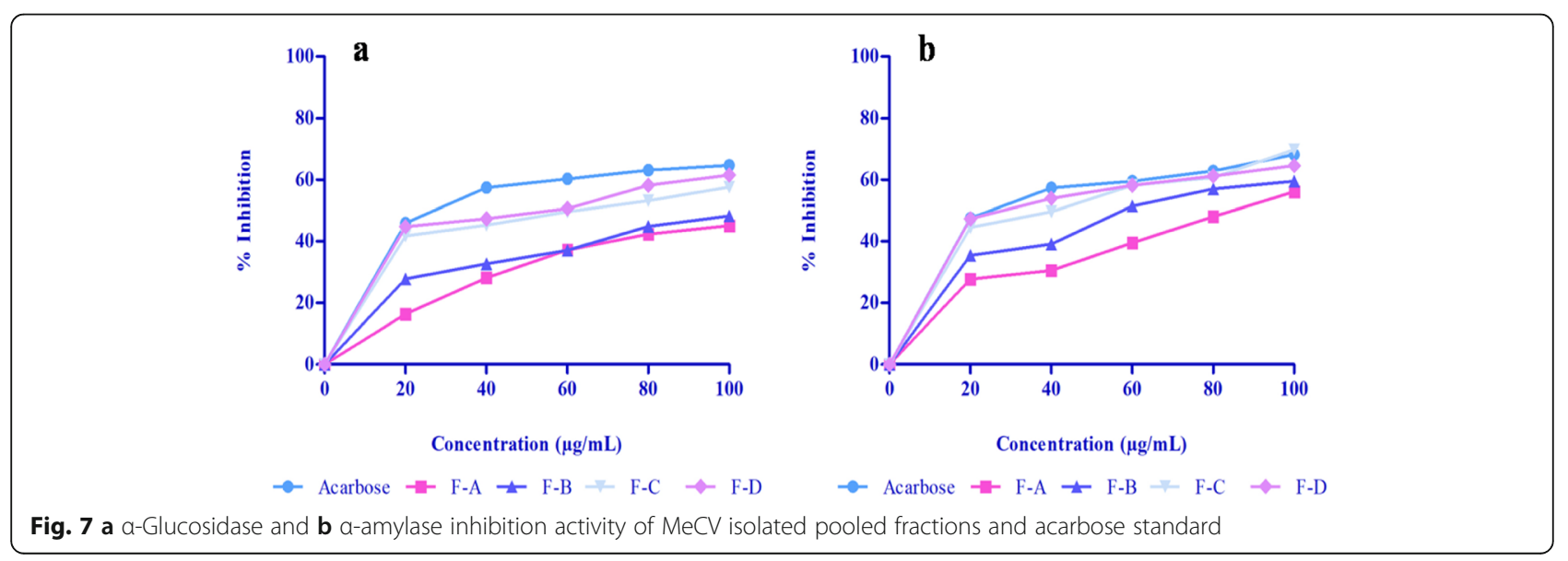




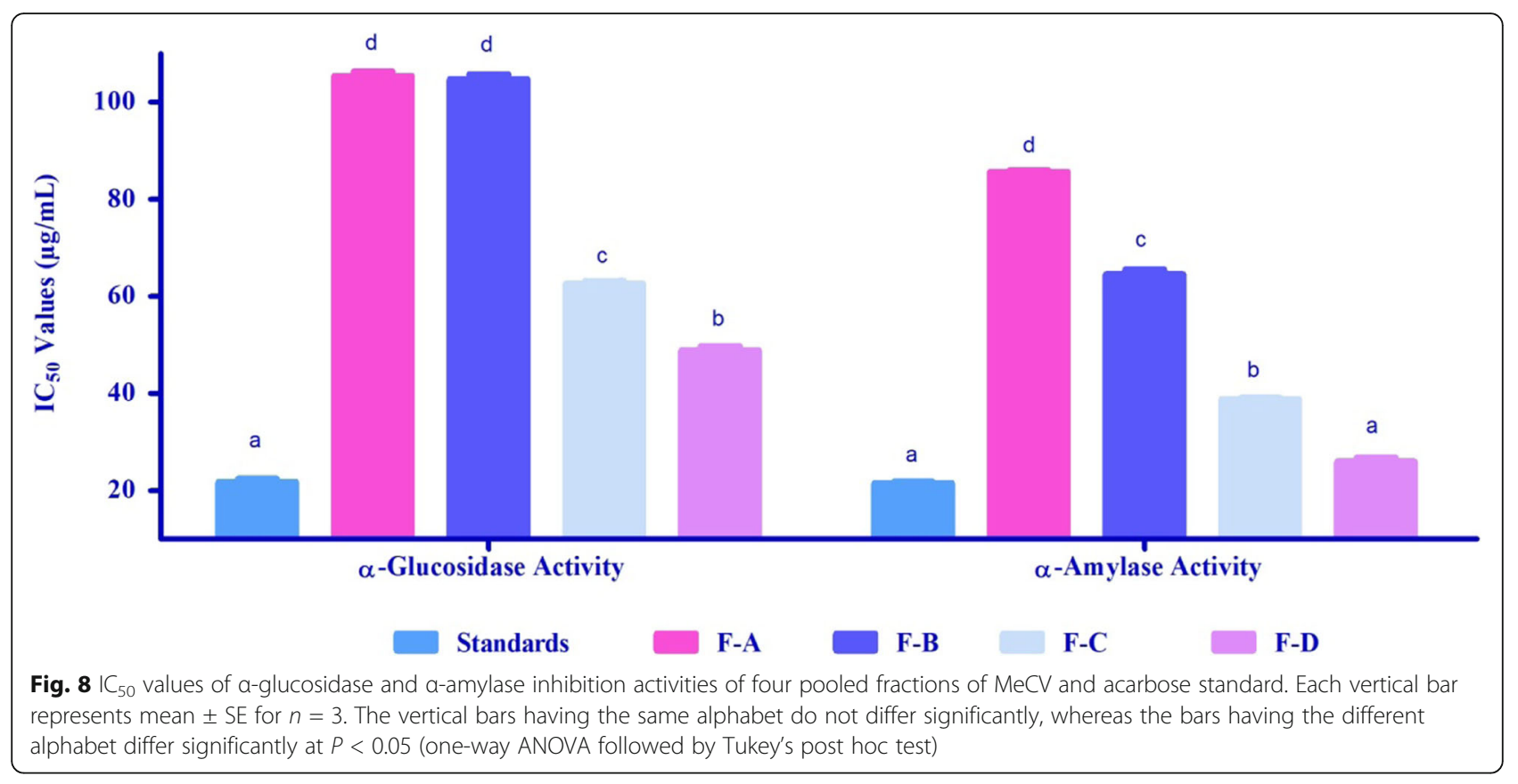

nonlinear correlation. At the same time, $\mathrm{O}_{2}{ }^{-}$exhibited a nonlinear correlation with DPPH, ABTS, and $\mathrm{H}_{2} \mathrm{O}_{2}$ along with this the $\alpha$-glucosidase was also a nonlinear correlation with ABTS, $\mathrm{H}_{2} \mathrm{O}_{2}, \mathrm{O}_{2}^{-}$, FRAP, and linear correlation with $\alpha$-amylase.

In $\mathrm{F}-\mathrm{C}$ and FRAP exhibited nonlinear correlation in TCP, TCF, DPPH, ABTS, $\mathrm{H}_{2} \mathrm{O}_{2}, \mathrm{O}_{2}^{-}$, FRAP, and $\alpha-$ Glucosidase while FRAP exhibited significant $(P<0.05)$ linear correlation with $\alpha$-amylase. DPPH exhibited nonlinear correlation in $\mathrm{H}_{2} \mathrm{O}_{2}$. In this fraction, $\alpha$-glucosidase and $\alpha$-amylase exhibited linear correlation in all in vitro activities (except FRAP) while a linear correlation occurred in between the TCP, TCF, DPPH, ABTS, $\mathrm{H}_{2} \mathrm{O}_{2}$, and $\mathrm{O}_{2}^{-}$.

F-D demonstrates that the TCP was a nonlinear correlation with DPPH and ABTS while TCF exhibited a nonlinear correlation with ABTS. DPPH exhibited a nonlinear correlation with FRAP and linear correlation exhibited with $\alpha$-glucosidase, $\alpha$-amylase, and the rest of the in-vitro antioxidant activities. ABTS demonstrated a strong nonlinear correlation with $\mathrm{H}_{2} \mathrm{O}_{2}, \mathrm{O}_{2}{ }^{-}$, FRAP, and $\alpha$-amylase while $\mathrm{H}_{2} \mathrm{O}_{2}$ exhibited a linear correlation with $\mathrm{O}_{2}{ }^{-}$, FRAP, $\alpha$-glucosidase, and $\alpha$-amylase.

On the whole, TCP and TCF demonstrated a strong linear correlation with the majority of antioxidant and antidiabetic activities in F-D while F-C, F-B, and F-A demonstrated the moderate and lesser linear correlation and strong nonlinear correlation. This strength may be attributed to the polyphenolic compounds under revealing in high-performance liquid chromatography (HPLC) analysis. The scavenging ability of free radical is a significant relation to avoid the oxidative stress interconnected in the direction of hyperglycemia [41]. The carbohydrate-metabolizing enzymes inhibitory activities were linearly correlated to TCP and TCF of F-D; though, it was also related to polyphenolic compounds [42]. The current correlation investigation specified that the $\alpha$-glucosidase and $\alpha$-amylase inhibition capability of the deliberated F-D might be accredited to their DPPH, ABTS, $\mathrm{H}_{2} \mathrm{O}_{2}$, $\mathrm{O}_{2}{ }^{-}$scavenging, and FRAP assets.

\section{Characterization of bioactive F-D fraction Detection of polyphenols by HPLC analysis}

In this study, the MeCV was purified by silica gel column chromatography. The obtained fractions were analyzed by TLC and bands were recognized. The bands among similar $R_{\mathrm{f}}$ was pooled and concentrated. Then among the four pooled fractions, F-D showed potent in vitro antioxidant and in vitro antidiabetic activity. Based on these outcomes, the bioactive F-D was subjected to scrutinize its purity by HPLC. Table 5 and Fig. 9 confirmed eight compounds by their retention time (RT). The unknown compounds characterized by peak 1-5 and 8 (Table 5) were available in the most noteworthy in the fraction. Major peaks were observed at $3.001 \mathrm{~min}(36.22 \%)$ and $4.523 \mathrm{~min}(39.05 \%)$ along with known compounds were also identified, i.e., protocatechuic acid hexoside (10.33\%) and rutin (4.08\%). This analysis could be qualified to the supportive liveliness between the various compounds [43, 44]. The eluted compounds were further conforming to partial structural elucidation through FTIR study. 
Table 4 Correlation coefficients of Pearson analysis to exhibit a linear correlation between phytochemical content, in vitro antioxidant and in vitro antidiabetic assays in MeCV isolated four pooled fractions

\begin{tabular}{|c|c|c|c|c|c|c|c|c|c|}
\hline Test samples & TCP & TCF & DPPH & ABTS & $\mathrm{H}_{2} \mathrm{O}_{2}$ & $\mathrm{O}_{2}^{-}$ & FRAP & a-glucosidase & a-amylase \\
\hline \multicolumn{10}{|l|}{ F-A } \\
\hline TCP & & -0.90 & -0.80 & -0.16 & $-0.99^{*}$ & 0.33 & -0.16 & -0.02 & 0.90 \\
\hline TCF & & & 0.98 & 0.57 & 0.92 & 0.10 & 0.58 & 0.45 & $-1.00^{* *}$ \\
\hline DPPH & & & & 0.71 & 0.84 & 0.28 & 0.71 & 0.60 & -0.98 \\
\hline ABTS & & & & & 0.22 & 0.87 & $1.00^{* *}$ & 0.99 & -0.57 \\
\hline $\mathrm{H}_{2} \mathrm{O}_{2}$ & & & & & & -0.27 & 0.22 & 0.08 & -0.92 \\
\hline $\mathrm{O}_{2}^{-}$ & & & & & & & 0.87 & 0.93 & -0.10 \\
\hline FRAP & & & & & & & & 0.98 & -0.58 \\
\hline a-glucosidase & & & & & & & & & -0.45 \\
\hline \multicolumn{10}{|l|}{$F-B$} \\
\hline $\mathrm{TCP}$ & & -0.46 & 0.94 & 0.63 & 0.24 & 0.01 & -0.33 & 0.73 & 0.85 \\
\hline TCF & & & -0.73 & -0.98 & -0.97 & 0.87 & -0.67 & 0.25 & -0.85 \\
\hline DPPH & & & & 0.85 & 0.56 & -0.32 & 0.004 & 0.46 & 0.98 \\
\hline ABTS & & & & & 0.90 & -0.76 & 0.51 & -0.05 & 0.94 \\
\hline $\mathrm{H}_{2} \mathrm{O}_{2}$ & & & & & & -0.96 & 0.82 & -0.47 & 0.71 \\
\hline $\mathrm{O}_{2}^{-}$ & & & & & & & -0.94 & 0.68 & -0.50 \\
\hline FRAP & & & & & & & & -0.88 & 0.20 \\
\hline a-glucosidase & & & & & & & & & 0.28 \\
\hline \multicolumn{10}{|l|}{$\mathrm{F}-\mathrm{C}$} \\
\hline TCP & & 0.84 & 0.56 & 0.89 & 0.35 & 0.99 & -0.93 & 0.97 & 0.92 \\
\hline TCF & & & 0.04 & 0.99 & 0.79 & 0.79 & -0.98 & 0.94 & 0.98 \\
\hline DPPH & & & & 0.14 & -0.57 & 0.64 & -0.23 & 0.35 & 0.21 \\
\hline ABTS & & & & & 0.72 & 0.85 & -0.99 & 0.97 & $0.99^{*}$ \\
\hline $\mathrm{H}_{2} \mathrm{O}_{2}$ & & & & & & 0.26 & -0.66 & 0.56 & 0.68 \\
\hline $\mathrm{O}_{2}^{-}$ & & & & & & & -0.89 & 0.94 & 0.88 \\
\hline FRAP & & & & & & & & -0.99 & $1.00^{*}$ \\
\hline a-glucosidase & & & & & & & & & 0.98 \\
\hline \multicolumn{10}{|l|}{$F-D$} \\
\hline $\mathrm{TCP}$ & & 0.41 & -0.05 & -0.98 & 0.97 & 0.77 & 0.98 & 0.06 & 0.21 \\
\hline TCF & & & 0.88 & -0.25 & 0.60 & 0.89 & 0.27 & 0.93 & 0.97 \\
\hline DPPH & & & & 0.27 & 0.16 & 0.58 & -0.20 & 0.99 & 0.96 \\
\hline ABTS & & & & & -0.92 & -0.65 & $-1.00^{*}$ & 0.10 & -0.04 \\
\hline $\mathrm{H}_{2} \mathrm{O}_{2}$ & & & & & & 0.89 & 0.93 & 0.28 & 0.42 \\
\hline $\mathrm{O}_{2}^{-}$ & & & & & & & 0.67 & 0.68 & 0.78 \\
\hline FRAP & & & & & & & & -0.08 & 0.06 \\
\hline a-glucosidase & & & & & & & & & 0.98 \\
\hline
\end{tabular}

Correlations significance considered at ${ }^{*} P<0.05$ and ${ }^{* *} P<0.01$. TCP total content of phenols, $T C F$ total content of flavonoids, DPPH DPPH radical scavenging activity, ABTS ABTS radical scavenging activity, $\mathrm{H}_{2} \mathrm{O}_{2} \mathrm{H}_{2} \mathrm{O}_{2}$ scavenging activity, $\mathrm{O}_{2}^{-}$superoxide radical scavenging activity, $F R A P$ ferric reducing antioxidant power, a-glucosidase a-glucosidase inhibition activity, a-amylase a-amylase inhibition activity

\section{Functional groups identification by FT-IR analysis}

The IR-spectrum of bioactive F-D was recorded by Thermo Nicolet-330 FTIR spectroscopy and results obtain the range under $400-4000 \mathrm{~cm}^{-1}$ IR region. From the absorption spectrum, the vibration assignments, wavenumber $\left(\mathrm{cm}^{-1}\right)$, along with intensities of main peaks were documented. The main peaks (see Fig. 10) of bioactive F-D signify the occurrence of various functional groups of compounds such as phenols, alcohols, alkanes and alkyls, amides, aliphatic amines, alkyl halides, and alkanes. The more strong bands occurring at 3298.28 $\mathrm{cm}^{-1}, 2924.09 \mathrm{~cm}^{-1}, 2854.65 \mathrm{~cm}^{-1}, 1595.13 \mathrm{~cm}^{-1}$, 
Table 5 HPLC validation data of bioactive F-D for polyphenol standards

\begin{tabular}{llll}
\hline Peak No & RT (min) & Compound name & \% Compound \\
\hline 1 & 3.001 & Unknown & 36.22 \\
2 & 4.523 & Unknown & 39.05 \\
3 & 5.214 & Unknown & 5.92 \\
4 & 5.982 & Unknown & 5.32 \\
5 & 7.090 & Unknown & 5.24 \\
6 & 7.434 & Protocatechuic acid hexoside & 10.33 \\
7 & 10.283 & Rutin & 4.08 \\
8 & 11.465 & Unknown & 3.16 \\
\hline
\end{tabular}

RT Retention time

$1357.89 \mathrm{~cm}^{-1}, 1195.87 \mathrm{~cm}^{-1}, 1080.14 \mathrm{~cm}^{-1}$, and 1043.49 $\mathrm{cm}^{-1}$ related to the stretch of $\mathrm{O}-\mathrm{H}, \mathrm{H}-, \mathrm{C}-\mathrm{H}, \mathrm{N}-\mathrm{H}, \mathrm{C}-$ $\mathrm{H}$ wag $(-\mathrm{CH} 2 \mathrm{X})$, and $\mathrm{C}-\mathrm{N}$ respectively (Table 6 ).

\section{Discussion}

The present study has been initiated to study C. viscosa plant as a potential antioxidant and antidiabetic agent. During this process, four isolated pooled fractions of $\mathrm{MeCv}$ were obtained to evaluate preliminary phytochemical screening, total phenolic and flavonoid content, and in-vitro antioxidant and antidiabetic property. The presence of phenolic compounds and their related functional groups were determined by HPLC and FTIR analysis.

The preliminary phytochemical screening was used to identify the secondary metabolites in the crude extracts of plants. In the present study, the preliminary phytochemical analysis revealed the presence of flavonoids, phenols, steroids, alkaloids, lignin, tannins, glycosides, terpenoids, saponins, quinines, and coumarins in the $\mathrm{MeCV}$. Medicinal and therapeutic properties of herbs are associated with their secondary metabolites. The effectiveness of the herbal remedies depends upon the solubility of these phytocompounds in various solvents. The results of preliminary phytochemical screening showed that the methanolic extract of C. viscosa (MeCV) whole plant has majority of phytochemicals. This may be due to the organic nature of methanol and its higher capacity to dissolve organic and active bioactive compounds [45]. The results of the present study confirm the previous studies, which have reported that methanol is a better solvent for more consistent extraction of compounds from medicinal plants compared to other solvents $[46,47]$.

Plants contain numerous phytochemical constituents, mainly polyphenols which are known to be biologically more active compounds and are responsible for exhibiting various pharmacological activities. The intervene plant polyphenols are significant wellspring of

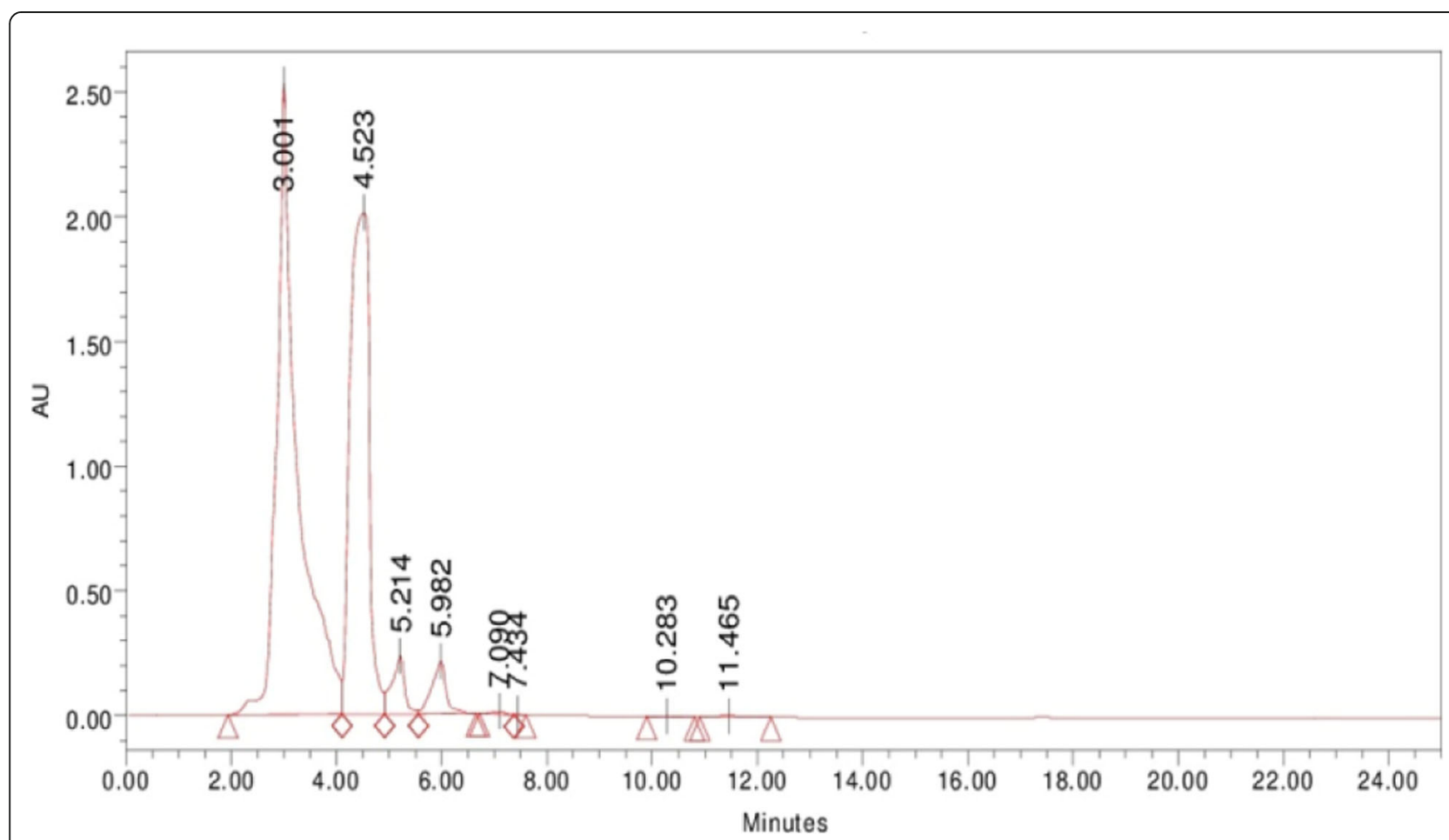

Fig. 9 Elution of polyphenols profile in bioactive F-D in HPLC. Major peaks were detected at 3.001 min and 4.523 min the elution was permitted up to $30 \mathrm{~min}$ 


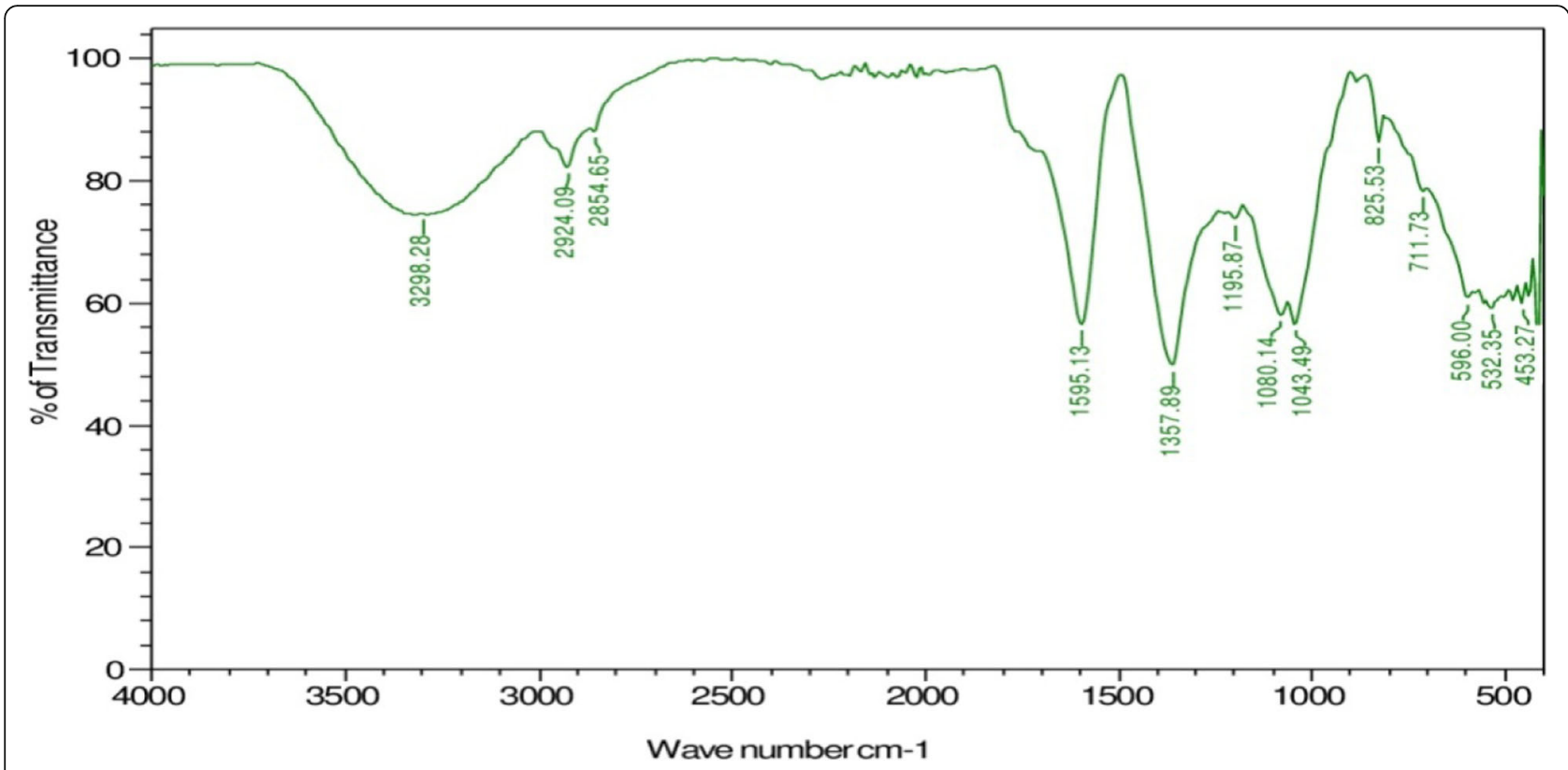

Fig. 10 FT-IR Spectrum scrutiny of bioactive F-D

natural antioxidants that are advanced larger than synthetic ones on account of safety concerns. The bioactive metabolites have been appeared to diminish the hazards and group of diseases, for example, cancer, cardiovascular, hepatotoxicity, neurodegenerative ailments, and so on by free radicals scavenging through different biological systems [48]. As indicated by Ananth et al. (2013), the free radical scavenging agents' action of polyphenols is to a great extent because of their redox properties which make them go about as lessening operators, donors of hydrogen, quenchers of singlet oxygen in addition to potential metal chelators [49]. In this examination, an impressive abnormal state of polyphenols (TCP and TCF) was seen in the F-D of the MeCV. This might clarify the broad traditional utilization of the plant.

In the current investigation, the increasing action of DPPH radical scavenging activity with increasing doses of the $\mathrm{MeCV}$ isolated fractions demonstrated an expanded capacity to give hydrogen particles bringing about a lighter arrangement which is corresponding to the number of electrons picked up [50]. Along these

Table 6 FT-IR peak values interpretation of bioactive F-D as follows

\begin{tabular}{llll}
\hline Peak value $\left(\mathbf{c m}^{-1}\right)$ & Assignment of functional group & The intensity of functional group & Identified groups \\
\hline 3298.28 & O-H stretch, H-bonded & Strong, broad & Alcohols, phenols \\
2924.09 & C-H stretch & Strong & Alkanes and alkyls \\
2854.65 & C-H stretch & Strong & Alkanes and alkyls \\
1595.13 & N-H bend & Medium-strong & Amides \\
1357.89 & C-H rock & Medium & Alkanes \\
1195.87 & C-H wag $(-\mathrm{CH} 2 \mathrm{X})$ & Medium & Alkyl halides \\
1080.14 & $\mathrm{C}-\mathrm{N}$ stretch & Medium & Aliphatic amines \\
1043.49 & $\mathrm{C}-\mathrm{N}$ stretch & Medium & Aliphatic amines \\
825.53 & $\mathrm{C}-\mathrm{Cl}$ stretch & Strong & Alkyl halides \\
711.73 & $\mathrm{C}-\mathrm{H}$ rock & Medium & Alkanes \\
596.00 & $\mathrm{C}-\mathrm{Cl}$ stretch & Medium & Alkyl halides \\
532.35 & $\mathrm{C}-\mathrm{Br}$ stretch & Medium & Alkyl halides \\
453.27 & $\mathrm{C}$-l stretch & Strong & Alkyl halides \\
\hline
\end{tabular}


lines, it might be assumed that the $\mathrm{MeCV}$ isolated fractions have DPPH radicals scavenging activity, by lessening the radical to relating hydrazine because of its capacity of donating hydrogen particle. However, DPPH radical scavenging activity is lower than that of ABTS radical scavenging activity of isolated pooled fractions from $\mathrm{MeCV}$. The chemical reaction of the radicals and the dissolvability of isolated fractions in various solvent systems are a few factors that have been accounted for to influence the limit of fractions to respond and quenching the various radicals [51]. Youn et al. (2019) found that the leaf extracts of Dendropanax morbifera have high ABTS scavenging activity than that of DPPH scavenging action [52].

As per Wu et al. (2006), the test of ABTS radical scavenging activity has been utilized as an index that revealed the antioxidant actions of test samples [53]. The ABTS radical scavenging activity of the $\mathrm{MeCV}$ isolated fractions in this study was observed to be as $92 \%$; same as the standard ascorbic acid at the $100 \mu \mathrm{g} / \mathrm{mL}$ of maximum dose. Subramanian and Ramani (2020) also found similar observations in the ABTS radical scavenging activity of different solvent extracts of Capparis brevispina DC leaves [54].

Hydrogen peroxide $\left(\mathrm{H}_{2} \mathrm{O}_{2}\right)$ occurs normally at low fixation levels noticeable all around, water, plants, human body, food, and microorganisms [55]. $\mathrm{H}_{2} \mathrm{O}_{2}$ is quickly decayed into $\mathrm{O}_{2}$ and $\mathrm{H}_{2} \mathrm{O}$ and this may create $\cdot \mathrm{OH}$ (hydroxyl radicals) that can start lipid peroxidation (LPO) and cause DNA damage [56]. In the current examination, $\mathrm{MeCV}$ isolated fractions productively scavenged $\mathrm{H}_{2} \mathrm{O}_{2}$ which might be ascribed to the nearness of polyphenols that could give electrons to $\mathrm{H}_{2} \mathrm{O}_{2}$, resulting in subsequent deactivation of $\mathrm{H}_{2} \mathrm{O}_{2}$ to $\mathrm{H}_{2} \mathrm{O}$. Adebiyi et al. (2017) also reported similar outcomes in the $\mathrm{H}_{2} \mathrm{O}_{2}$ scavenging activity of different solvent extracts of Grewia carpinifolia [57].

Superoxide radical $\left(\mathrm{O}_{2}^{-}\right)$is estimated as an important natural resource of reactive oxygen species (ROS) [58]. However, the $\mathrm{O}_{2}{ }^{-}$is a delicate oxidant; it suggests mount to potent and chain-breaking hydroxyl radicals $(\cdot \mathrm{OH})$ and singlet oxygen $(\mathrm{O} 2)$ [59]. The aftereffects of our investigation revealed that F-D has a viable limit of scavenging capacity for $\mathrm{O}_{2}$ and connected with total phenolic and flavonoid content along these lines recommending its antioxidant potential. Ketha et al. (2020) found the comparative impacts against superoxide radical scavenging action of methanolic solvent extracts of Cardiospermum canescens synthetic compounds which are in charge of their activity [60].

FRAP test was especially used to assess the measure of cell reinforcement or reductants nearness in a test sample that reacts with colorless Fe3+-TPTZ (ferric tripyridyltriazine) complex and structures a dark blue color Fe2+-TPTZ (ferrous tripyridyltriazine) complex [36]. In our present investigation, F-D demonstrated the most elevated and diminishing power followed by the FA, F-B, and F-C. The compounds synthesized from Anacardium occidentale leaf extracts and Clinacanthus nutans whole plant have similar results [61, 62]. In this measure, redox reaction occurs in decreases $\mathrm{Fe} 3+$ to $\mathrm{Fe} 2+$ which contributes an electron in the nearness of antioxidants in the test sample.

Based on the results of above free radical scavenging activities, it is confirmed that the isolated pooled fractions obtained from $\mathrm{MeCV}$ acts as potential antioxidant agents. Generally, antioxidants are substances organized to scavenging or controlling the oxidation of the particles. Previously, the therapeutic field focused on antioxidant therapy in the management of various diseases, particularly diabetes. Before conducting the exploratory studies, the clinical trials have proved the capability of antioxidants in avoiding diabetic complications. In most of the cases, therapeutic plants with antioxidant action are considered for the treatment of diabetes mellitus [63].

The main objective of the treatment of diabetic patients during the period of treatment is to maintain the normal range of glucose in fasting and postprandial condition. The present study revealed the capacity of isolated pooled fraction obtained from $\mathrm{MeCV}$ was controlled glucose diffusion using in vitro method. In particularly, F-D demonstrates the potential inhibitory action of glucose diffusion increment that may be helpful for permit flexibility in meal plan in NIDDM. Our results are similar to Basha and Kumari (2012); the four various solvent extracts of Psidium guajava has a significant effect against the inhibitory impact on glucose diffusion [64].

Garg and Baliga (2002) also proved that controlling postprandial hyperglycaemia is a viable method for the management of diabetes mellitus particularly in NIDDM [65]. This can be proficient by inhibiting primary carbohydrate hydrolyzing enzymes, i.e., $\alpha$-glucosidase and $\alpha$ amylase (Fig. 7a and b) in the gastrointestinal tract. The capacity of the F-D to inhibit $\alpha$-glucosidase and $\alpha$ amylase in a dose-dependent manner might be credited to polyphenols in the fraction, which correspond with the report of Garg and Baliga (2002) [65]. The inhibitory properties of $\alpha$-glucosidase and $\alpha$-amylase by the F-D might be valuable in controlling the symptoms, i.e., flatulence, abdominal distention, and diarrhea. In this investigation, it very well may be reasoned that F-D restrained the movement of $\alpha$-glucosidase and $\alpha$-amylase (Fig. 8) in an equal manner of standard acarbose respectively. This might be credited to the rich substance of polyphenols in the part. 
Taking everything into account, among the four isolated pooled fractions, F-D has a strong antioxidant property for treating diabetes and their related complications. Therefore, we have decided to choose F-D fraction for possible bioactive polyphenolic compounds detected by using HPLC analysis. The identified polyphenolic compounds were summarized in Table 5. The peaks of these compounds were recorded at $280 \mathrm{~nm}$ and were identified by comparison with standard compounds of polyphenols. However, the antidiabetic activity of the MeCV isolated F-D may be attributed to the presence of these compounds.

FTIR identifies and elucidates the chemical constituents which provide accurate measurements of the whole range of biological samples [66]. The F-D of MeCV exhibited phenols, alcohols, alkanes and alkyls, amides, aliphatic amines, alkyl halides, and alkanes. Identification and elucidation of polyphenols in the F-D was confirmed due to strong $\mathrm{O}-\mathrm{H}$ and $\mathrm{H}$-bonded stretching which is representing the phenols and alcohol functional groups. Similar results are reported by Choudhary and Mishra [67]. The peak at $2924.09 \mathrm{~cm}^{-1}$ and $2854.65 \mathrm{~cm}^{-1}$ is a strong $\mathrm{C}-\mathrm{H}$ bonding stretch due to ether linkage and it indicates the adsorbed on the surface of F-D fraction. The presence of alkanes, alkyls, amides, aliphatic amines, alkyl halides, and alkanes in F-D may represent the other group of phytochemicals, which are present in the crude $\mathrm{MeCV}$ by preliminary phytochemical screening. These outcomes are similar with Maobe and Nyarango (2013) who stated that the functional groups of carboxylic acids, anhydrides, alcohols, phenols, amines, amides, esters, organic halogens, and carbohydrate could be responsible for the various medicinal properties of Grewia tilifolia [68].

However, the result we got in the present study is similar to several other documentation on the antioxidant therapy in the management of diabetes [67]. Recently, Gudise et al. (2019) also demonstrated that Argyreia pierreana and Matelea denticulata leaf extracts possess high antioxidant and antidiabetic potential which contains a high content of polyphenols [69]. The inhibitory effect on key enzymes is relevant to acute type- 2 diabetes effect of ethanolic extract of Artocarpus heterophyllus antioxidant effects [70].

\section{Conclusion}

Findings from this investigation revealed that the $\mathrm{MeCv}$ isolated FD fraction showed higher glucose dispersion, $\alpha$-glucosidase and $\alpha$-amylase inhibitory potential, and antioxidant property. This superior activity of FD fraction might be due to their high phenolic and flavonoid content than the remaining three fractions. These results recommended that the plant of C. viscosa can be taken as a good natural source of remedial medicine for diabetes. However, further studies are needed to evaluate the accurate hypoglycemic and antioxidant effect of FD pooled fraction in order to utilize C. viscosa as a natural antioxidant and an antidiabetic agent.

\section{Abbreviations}

AAE: Ascorbic acid equivalents; ABTS: 2,2'-Azino-bis(3-ethylbenzothiazoline-6sulfonic acid); ANOVA: Analysis of variance; CMC: Carboxymethyl cellulose; DNA: Deoxy ribonuclease; DPPH: 2,2-Diphenyl-1-picrylhydrazyl; DW: Dry weight; FRAP: Ferric reducing antioxidant power; FT-IR: Fourier transform infrared; GAE: Gallic acid equivalents; GDRI: Glucose dialysis retardation index; $\mathrm{H}_{2} \mathrm{O}$ : Water; $\mathrm{H}_{2} \mathrm{O}_{2}$ : Hydrogen peroxide; HPLC: High-performance liquid chromatography; IC 50 : Inhibitory concentration at 50\%; LPO: Lipid peroxidation; MeCV: Methanolic extract from traditional Cleome viscosa NAD: Nicotinamide adenine dinucleotide; NBT: Nitro blue tetrazolium chloride; NIDDM: Noninsulin-dependent diabetes mellitus; $\mathrm{O}_{2}{ }^{-} \cdot$ : Superoxide radicals; $\mathrm{OH} \cdot$ : Hydroxyl radical; PBS: Phosphate buffer saline; PMS: Phenazine methosulfate; QRE: Quercetin equivalents; Rf: Retention factor; ROS: Receptive oxygen species; RT: Retention times; SE: Standard error; SPSS: Statistical Package for the Social Sciences; TLC: Thin-layer chromatography; TPTZ: 2,4,6Tris(2-pyridyl)-s-triazine

\section{Acknowledgement}

The authors thank Dravidian University, Kuppam for providing necessary support for this research work.

\section{Plant authentication}

The Cleome viscosa (Family: Cleomaceae) whole plant material was identified and validating (No. NY/531) by Prof. N. Yasodamma, Taxonomist, Department of Botany, S.V. University, Tirupati, India.

\section{Authors' contributions}

YS participated in conceptualizing the study and designed the study, conducted the research, optimized methods, and participated in conceptualizing the study, drafting, and revising the manuscript. GR helped in conducting research methods, entering data and revising the manuscript. TL participated in conceptualizing the study, drafting and revising the manuscript. BLN participated in entering data and revising the manuscript. KSR participated in conceptualizing and supervising the study, revising the manuscript, and review. SRR conceptualized and designed the study, drafted and revised the manuscript, analyzed data and supervised the research work, review and editing. All authors had perused and approve the final edition of manuscript and consent to be responsible for all parts of the work in guaranteeing that questions related to the work are properly examined and resolved.

\section{Funding}

UGC-RGNF (F1-17.1/2016-17/RGNF-2015-17-SC-AND 6017/ (SAll/Website)) providing the financial support.

Availability of data and materials

Data and material are available upon request.

Ethics approval and consent to participate

Not applicable.

Consent for publication

Not applicable.

\section{Competing interests}

There is no competing of interests.

\section{Author details}

'Division of Ethnopharmacology, Department of Biotechnology, School of Herbal studies and Naturo Sciences, Dravidian University, Kuppam, Andhra Pradesh 517426, India. ${ }^{2}$ Department of Zoology, Sri Venkateswara University, Tirupati, Andhra Pradesh 517502, India. 
Received: 29 June 2020 Accepted: 4 October 2020

Published online: 27 November 2020

\section{References}

1. Cho N, Shaw JE, Karuranga S, Huang Y, da Rocha Fernandes JD, Ohlrogge AW, Malanda B (2018) IDF Diabetes Atlas: global estimates of diabetes prevalence for 2017 and projections for 2045. Diabetes Res. Clin. Pract 138 271-281. https://doi.org/10.1016/j.diabres.2018.02.023

2. Kuruppu Al, Paranagama P, Goonasekara CL (2019) Medicinal plants commonly used against cancer in traditional medicine formulae in Sri Lanka. Saudi Pharm J27(4):565-573. https://doi.org/10.1016/j.jsps.2019.02.004

3. Shori $A B$ (2015) Screening of antidiabetic and antioxidant activities of medicinal plants. J. Integr. Med 13(5):297-305. https://doi.org/10.1016/ S2095-4964(15)60193-5

4. Paramaguru R, Mazumder PM, Sasmal D, Jayaprakash V $(2014,2014)$ Antidiabetic activity of Pterospermumacerifolium flowers and glucose uptake potential of bioactive fraction in L6 muscle cell lines with its HPLC fingerprint. Biomed Res. Int. https://doi.org/10.1155/2014/459376

5. Sepici A, Gürbüz I, Çevik C, Yesilada E (2004) Hypoglycaemic effects of myrtle oil in normal and alloxan-diabetic rabbits. J. Ethnopharmacol 93(2-3): 311-318. https://doi.org/10.1016/j.jep.2004.03.049

6. Gupta R, Gigras P, Mohapatra H, Goswami VK, Chauhan B (2003) Microbial a-amylases: a biotechnological perspective. Process Biochem 38(11):1599-1616

7. Wild S, Roglic G, Green A, Sicree R, King H (2004) Global prevalence of diabetes: estimates for the year 2000 and projections for 2030. Diabetes care 27(5):1047-1053. https://doi.org/10.2337/diacare.27.5.1047

8. Matsui T, Ueda T, Oki T, Sugita K, Terahara N, Matsumoto K (2001) aGlucosidase inhibitory action of natural acylated anthocyanins. 1. Survey of natural pigments with potent inhibitory activity. J. Agric. Food Chem 49(4): 1948-1951. https://doi.org/10.1021/jf001251u

9. DiNicolantonio JJ, Bhutani J, O'Keefe JH (2015) Acarbose: safe and effective for lowering postprandial hyperglycaemia and improving cardiovascular outcomes. Open heart 2(1):e000327. https://doi.org/10.1136/openhrt2015-000327

10. Chaudhury A, Duvoor C, Reddy Dendi VS, Kraleti S, Chada A, Ravilla R, Marco A, Shekhawat NS, Montales MT, Kuriakose K, Sasapu A (2017) Clinical review of antidiabetic drugs: implications for type 2 diabetes mellitus management. Front Endocrinol 8:6. https://doi.org/10.3389/fendo.2017.00006

11. FatimaM SS, Nazir SU (2018) Metformin and its gastrointestinal problems: A review. Biomed. Res 29:2285-2289. https://doi.org/10.4066/ biomedicalresearch.40-18-526

12. Siavash M, Tabbakhian M, Sabzghabaee AM, Razavi N (2017) Severity of gastrointestinal side effects of metformin tablet compared to metformin capsule in type 2 diabetes mellitus patients. J Res Pharm Pract 6(2):73. https://doi.org/10.4103/jrpp.JRPP_17_2

13. Quan NV, Xuan TD, Tran HD, Thuy NT, Trang LT, Huong CT, Andriana Y, Tuyen PT (2019) Antioxidant, a-amylase and a-glucosidase inhibitory activities and potential constituents of 8 Canarium tramdenum bark. Molecules 24(3):605. https://doi.org/10.3390/molecules24030605

14. Chelladurai GR, Chinnachamy C (2018) Alpha amylase and Alpha glucosidase inhibitory effects of aqueous stem extract of Salacia oblonga and its GC-MS analysis. Braz. J. Pharm. Sci 54(1). https://doi.org/10.1590/ s2175-97902018000117151

15. Juárez-Reyes K, Brindis F, Medina-Campos ON, Pedraza-Chaverri J, Bye R, Linares E, Mata R (2015) Hypoglycemic, antihyperglycemic, and antioxidant effects of the edible plant Anodacristata. J. Ethnopharmacol 161:36-45. https://doi.org/10.1016/j.jep.2014.11.052

16. Uttara B, Singh AV, Zamboni P, Mahajan RT (2009) Oxidative stress and neurodegenerative diseases: a review of upstream and downstream antioxidant therapeutic options. Curr. Neuropharmacol 7(1):65-74. https:// doi.org/10.2174/157015909787602823

17. Godwill Azeh Engwa (2018). Free radicals and the role of plant phytochemicals as antioxidants against oxidative stress-related diseases, phytochemicals - source of antioxidants and role in disease prevention, Toshiki Asao and Md Asaduzzaman, IntechOpen. https://doi.org/10.5772/ intechopen.76719

18. Wang TY, Li Q, Bi KS (2018) Bioactive flavonoids in medicinal plants: structure, activity and biological fate. Asian J. Pharm. Sci 13(1):12-23. https:// doi.org/10.1016/j.ajps.2017.08.004
19. Forni C, Facchiano F, Bartoli M, Pieretti S, Facchiano A, D'Arcangelo D, Norelli S, Valle G, Nisini R, Beninati S, Tabolacci C $(2019,2019)$ Beneficial role of phytochemicals on oxidative stress and age-related diseases. Biomed Res. Int. https://doi.org/10.1155/2019/8748253

20. Upadhyay A, Chattopadhyay P, Goyary D, Mazumder PM, Veer V (2014, 2014) Topical application of Cleome viscosa increases the expression of basic fibroblast growth factor and type III collagen in rat cutaneous wound. Biomed Res. Int. https://doi.org/10.1155/2014/680879

21. Yadav NP, Chanda D, Chattopadhyay SK, Gupta AK, Pal A (2010) Hepatoprotective effects and safety evaluation of coumarinolignoids isolated from Cleome viscosa seeds. Indian J. Pharm. Sci. 72(6):759-765. https://doi.org/10.4103/0250-474X.84589

22. Gupta NK, Dixit VK (2009) Evaluation of hepatoprotective activity of Cleome viscosa Linn. extract. Indian J. Pharmacol 41(1):36-40. https://doi.org/10. 4103/0253-7613.48892

23. Soni LK, Dobhal MP, Arya D, Bhagour K, Parasher P, Gupta RS (2018) In vitro and in vivo antidiabetic activity of isolated fraction of Prosopis cineraria against streptozotocin-induced experimental diabetes: a mechanistic study. Biomed Pharmacother. 1(108):1015-1021. https://doi.org/10.1016/j.biopha. 2018.09.099

24. Gibbs RD (1974) Chemotaxonomy of flowering plants: four volumes. Montreal: McGill-Queen's University Press-MQUP

25. Evans WC (2002) Trease and Evans Pharmacognosy. 15th edn. Sanders Co. Ltd., Singapore

26. Kokate TG, Yamaguchi SI, Pannell LK, Rajamani U, Carroll DM, Grossman AB, Rogawski MA (1998) Lack of anticonvulsant tolerance to the neuroactive steroid pregnanolone in mice. J Pharmacol Exp Ther 287(2):553-558 PMID 9808680

27. Rizk AM (1982) Constituents of plants growing in Quatar. 1. A chemical survey of sixty plants. Fitoterapia. 53:35-44

28. Khoo LT, Abdullah JO, Abas F, Tohit ER, Hamid M (2015) Bioassay-guided fractionation of Melastoma malabathricum Linn. leaf solid phase extraction fraction and its anticoagulant activity. Molecules. 20(3):3697-3715. https:// doi.org/10.3390/molecules20033697

29. Gujjeti RP, Mamidala E (2017) Anti-HIV Activity of Phytosterol Isolated from Aervalanata Roots. Pharmacogn J. 9(1):112-116. https://doi.org/10.5530/pj. 2017.1.19

30. Singleton VL, Rossi JA (1965) Colorimetry of total phenolics with phosphomolybdic-phosphotungstic acid reagents. Am J Enol Viticult 16(3): 144-158

31. Chang CC, Yang MH, Wen HM, Chern JC (2002) Estimation of total flavonoid content in propolis by two complementary colorimetric methods. J Food Drug Anal 10(3):178-182

32. Brand-Williams W, Cuvelier ME, Berset CL (1995) Use of a free radical method to evaluate antioxidant activity. LWT-Food Sci Technol 28(1):25-30. https://doi.org/10.1016/S0023-6438(95)80008-5

33. Re R, Pellegrini N, Proteggente A, Pannala A, Yang M, Rice-Evans C (1999) Antioxidant activity applying an improved ABTS radical cation decolorization assay. Free Radic. Biol. Med 26(9-10):1231-1237. https://doi. org/10.1016/S0891-5849(98)00315-3

34. Ruch RJ, Cheng SJ, Klaunig JE (1989) Prevention of cytotoxicity and inhibition of intercellular communication by antioxidant catechins isolated from Chinese green tea. Carcinogenesis 10(6):1003-1008. https://doi.org/10. 1093/carcin/10.6.1003

35. Nishikimi M, Rao NA, Yagi K (1972) The occurrence of superoxide anion in the reaction of reduced phenazine methosulfate and molecular oxygen. Biochem. Biophys. Res. Commun 46(2):849-854. https://doi.org/10.1016/ S0006-291X(72)80218-3

36. Benzie IF, Strain JJ (1996) The ferric reducing ability of plasma (FRAP) as a measure of "antioxidant power": the FRAP assay. Anal. Biochem 239(1):70 76. https://doi.org/10.1006/abio.1996.0292

37. Edwards CA, Blackburn NA, Craigen L, Davison P, Tomlin J, Sugden K, Johnson IT, Read NW (1987) Viscosity of food gums determined in vitro related to their hypoglycemic actions. Am. J. Clin. Nutr 46(1):72-77. https:// doi.org/10.1093/ajen/46.1.72

38. Yin Z, Zhang W, Feng F, Zhang Y, Kang W (2014) a-Glucosidase inhibitors isolated from medicinal plants. Food Sci Hum Wellness 3(3-4):136-174 https://doi.org/10.1016/j.fshw.2014.11.003

39. Hansawasdi C, Kawabata J, Kasai T (2000) a-Amylase inhibitors from roselle (Hibiscus sabdariffa Linn.) tea. Biosci. Biotechnol. Biochem 64(5):1041-1043. https://doi.org/10.1271/bbb.64.1041 
40. Rupasinghe HP, Boehm M, Sekhon-Loodu S, Parmar I, Bors B, Jamieson AR (2015) Anti-inflammatory activity of haskap cultivars is polyphenolsdependent. Biomolecules 5(2):1079-1098. https://doi.org/10.3390/ biom5021079

41. Sekhon-Loodu S, Rupasinghe HP (2019) Evaluation of antioxidant, antidiabetic and antiobesity potential of selected traditional medicinal plants. Front Neurol 6:53. https://doi.org/10.3389/fnut.2019.00053

42. Ademiluyi AO, Oboh G (2013) Soybean phenolic-rich extracts inhibit keyenzymes linked to type 2 diabetes (a-amylase and a-glucosidase) and hypertension (angiotensin I converting enzyme) in vitro. Exp. Toxicol. Pathol 65(3):305-309. https://doi.org/10.1016/j.etp.2011.09.005

43. Ouerghemmi S, Sebei H, Siracusa L, Ruberto G, Saija A, Cimino F, Cristani M (2016) Comparative study of phenolic composition and antioxidant activity of leaf extracts from three wild Rosa species grown in different Tunisia regions: Rosa canina L., Rosa moschataHerrm. and Rosa sempervirens L. Ind Crops Prod 94:167-177

44. Paranthaman R, Sudha A, Kumaravel S (2012) Determination of pesticide residues in banana by using high performance liquid chromatography and gas chromatography-mass spectrometry. Am J Biochem Biotechnol 8(1):1-6. https://doi.org/10.3844/ajbbsp.2012.1.6

45. Cowan MM (1999) Plant products as antimicrobial agents. Clin. Microbiol. Rev. 12(4):564-582. https://doi.org/10.1128/CMR.12.4.564

46. Mondal M, Hossain MS, Das N, Khalipha AB, Sarkar AP, Islam MT, Smrity SZ, Biswas S, Kundu SK (2019) Phytochemical screening and evaluation of pharmacological activity of leaf Methanolic extract of Colocasiaaffinis Schott. Clin Phytoscience. 5(1):8. https://doi.org/10.1186/s40816-019-0100-8

47. Rakib-Uz-Zaman SM, Iqbal A, Mowna SA, Khanom MG, Al Amin MM, Khan K (2020) Ethnobotanical study and phytochemical profiling of Heptapleurumhypoleucum leaf extract and evaluation of its antimicrobial activities against diarrhea-causing bacteria. J Genetic Eng Biotechnol. 18(1): 1-3. https://doi.org/10.1186/s43141-020-00030-0

48. Karthika K, Gargi G, Jamuna S, Paulsamy S, Ali MA, Al-Hemaid F, Elshikh MS, Lee J (2019) The potential of antioxidant activity of methanolic extract of Cosciniumfenestratum (Goetgh.) Colebr (Menispermaceae). Saudi J. Biol. Sci 26(5):1037-1042. https://doi.org/10.1016/j.sjbs.2018.08.010

49. Ananth DA, Sivasudha T, Rameshkumar A, Jeyadevi R, Aseervatham SB (2013) Chemical constituents, in vitro antioxidant and antimicrobial potential of Caryotaurens L. Free Radic. Biol. Med 3(2):107-112. https://doi.org/10. 3390/biomedicines4030017

50. Mezadri T, Villaño D, Fernández-Pachón MS, García-Parrilla MC, Troncoso AM (2008) Antioxidant compounds and antioxidant activity in acerola (Malpighia emarginata DC.) fruits and derivatives. J. Food Compos. Anal 21(4):282-290. https://doi.org/10.1016/j.jfca.2008.02.002

51. Mtunzi FM, Ejidike IP, Ledwaba I, Ahmed A, Pakade VE, Klink MJ, Modise SJ (2017) Solvent-solvent fractionations of Combretum erythrophyllum (Burch.) leave extract: studies of their antibacterial, antifungal, antioxidant and cytotoxicity potentials. Asian Pac. J. Trop. Med 10(7):670-679. https://doi. org/10.1016/j.apjtm.2017.07.007

52. Youn JS, Kim YJ, Na HJ, Jung HR, Song CK, Kang SY, Kim JY (2019) Antioxidant activity and contents of leaf extracts obtained from Dendropanaxmorbifera LEV are dependent on the collecting season and extraction conditions. Food Sci. Biotechnol 28(1):201-207. https://doi.org/10. 1007/s10068-018-0352-y

53. Wu LC, Hsu HW, Chen YC, Chiu CC, Lin Yl, Ho JA (2006) Antioxidant and antiproliferative activities of red pitaya. Food Chem 95(2):319-327. https:// doi.org/10.1016/j.foodchem.2005.01.002

54. Subramanian SK, Ramani P (2020) Antioxidant and cytotoxic activities of Indian caper (Capparis brevispina DC (Capparaceae)) leaf extracts. Eur J Integr Med 33:101038. https://doi.org/10.1016/j.eujim.2019.101038

55. Gülçin I, Berashvili D, Gepdiremen A (2005) Antiradical and antioxidant activity of total anthocyanins from Perilla pankinensisdecne. J Ethnopharmacol 101(1-3):287-293. https://doi.org/10.1016/j.jep.2005.05.006

56. Sahreen S, Khan MR, Khan RA (2011) Phenolic compounds and antioxidant activities of Rumexhastatus D. Don. Leaves. J Med Plants Res 5(13):2755-2765

57. Adebiyi OE, Olayemi FO, Ning-Hua T, Guang-Zhi Z (2017) In vitro antioxidant activity, total phenolic and flavonoid contents of ethanol extract of stem and leaf of Grewiacarpinifolia. Beni-Seuf Univ. J. Appl. Sci 6(1):10-14. https:// doi.org/10.1016/j.bjbas.2016.12.003
58. Phaniendra A, Jestadi DB, Periyasamy $L$ (2015) Free radicals: properties, sources, targets, and their implication in various diseases. Indian J Clin Biochem 30(1):11-26. https://doi.org/10.1007/s12291-014-0446-0

59. Augusto O, Miyamoto S (2011) Oxygen radicals and related species. Principles of free radical biomedicine, vol 1. New York: Nova Science Publishers, Inc; pp 19-42

60. Ketha A, Vedula GS, Sastry AV (2020) In vitro antioxidant, anti-inflammatory, and anticancer activities of methanolic extract and its metabolites of whole plant Cardiospermum canescens Wall. Future J. Pharm. Sci 6:1-0. https://doi. org/10.1186/s43094-020-00028-y

61. Ajileye OO, Obuotor EM, Akinkunmi EO, Aderogba MA (2015) Isolation and characterization of antioxidant and antimicrobial compounds from Anacardium occidentale L. (Anacardiaceae) leaf extract. J. King Saud Univ. Sci 27:244-252. https://doi.org/10.1016/j.jksus.2014.12.004

62. Hamid HA, Yahya IH, Yusoff MM, Zareen S (2016) Bioassay-guided isolation and antioxidant activity of sulfur-containing compounds from Clinacanthus nutans. J Chin Chem Soc-Taip 63(12):1033-1037. https://doi.org/10.1016/j. bioorg.2019.03.041

63. Kooti W, Farokhipour M, Asadzadeh Z, Ashtary-Larky D, Asadi-Samani M (2016) The role of medicinal plants in the treatment of diabetes: a systematic review. Electron. Physician 8(1):1832-1842. https://doi.org/10. 19082/1832

64. Basha SK, Kumari VS (2012) In vitro antidiabetic activity of Psidium guajava leaves extracts. Asian Pac. J. Trop. Dis 2:S98-S100. https://doi.org/10.3390/ ijms18040897

65. Garg MK, Baliga KV (2002) Management of type 2 diabetes (NIDDM). Med J. Armed Forces India 58:53-59. https://doi.org/10.1016/S03771237(02)80014-4

66. Kumar TT, Salique SM, Ilyas MH, Thajuddin N, Panneerselvam A, Padusha MK, Jahangir HS (2018) Phytochemical screening and antimicrobial studies in leaf extracts of indigoferaaspalathoides (Vahl.). Pharmacognosy J. 10(6): 1208-1215. https://doi.org/10.5530/pj.2018.6.207

67. Choudhary DK, Mishra A (2017) In vitro and in silico interaction of porcine aamylase with Viciafaba crude seed extract and evaluation of antidiabetic activity. Bioengineered 8(4):393-403. https://doi.org/10.1080/21655979.2016. 1235102

68. Maobe MA, Nyarango RM (2013) Fourier transformer infra-red spectrophotometer analysis of Warburgiaugandensis medicinal herb used for the treatment of diabetes, malaria and pneumonia in Kisii Region, Southwest Kenya. Global J Pharmacol 7(1):61-68. https://doi.org/10.5829/ idosi.gjp.2013.7.1.7226

69. Gudise V, Chowdhury B, Manjappa AS (2019) In vitro free radical scavenging and antidiabetic activity of aqueous and ethanolic leaf extracts: a comparative evaluation of Argyreiapierreana and Mateleadenticulata. Future J. Pharm. Sci 5(1):1-1. https://doi.org/10.1186/s43094-019-0014-9

70. Ajiboye BO, Ojo OA, Adeyonu O, Imiere O, Olayide I, Fadaka A, Oyinloye BE (2016) Inhibitory effect on key enzymes relevant to acute type-2 diabetes and antioxidative activity of ethanolic extract of Artocarpusheterophyllus stem bark. J. Acute Dis 5(5):423-429. https://doi. org/10.1016/j.joad.2016.08.011

\section{Publisher's Note}

Springer Nature remains neutral with regard to jurisdictional claims in published maps and institutional affiliations. 